UCRL -53227

DE8 2009041

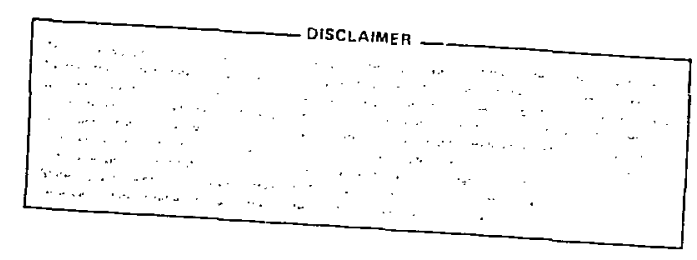

\title{
Excavation and Drilling at a Spent-Fuel Test Facility in Granitic Rock
}

\author{
W. C. Patrick \\ M. C. Mayr
}

Manuscript date: October 1981

\section{LAWRENCE LIVERMORE LABORATORY University of California - Livermore, California 94550}




\section{ABSTRACT}

Funding for a project to test the feasibility of safe and reliable storage and retrieval of spent fuel from a commercial nuclear reactor was approved by the Department of Energy on June 2, 1978. By May 28, 1980, 11 spent-fuel assemblies had been emplaced $420 \mathrm{~m}$ below the surface in the climax granitic stock at the Nevada Test Site. Design and construction of the Spent Fuel Test-climax, including fuel emplacement, had taken less than two years, at a total cost of $\$ 18.4$ million.

Construction activities were preceded by geologic exploration using four cored holes and existing underground workings. The sinking of a $0.76-\mathrm{m}-\mathrm{diam}$ shaft to the $420-\mathrm{m}$ level initiated construction at the site. Effective rates of sinking varied from $0.16 \mathrm{~m} / \mathrm{h}$ with a rotary tricone drill to $0.5 \mathrm{~m} / \mathrm{h}$ with a hammer drill. Underground excavation included a central canister-storage drift $4.6 \times 6.1 \times 64 \mathrm{~m}$ long, two parallel $3.4 \times 3.4-\mathrm{m}$ heater drifts, and a tail

drift. About $6700 \mathrm{~m}^{3}$ were excavared at an average rate of $2 \mathrm{~m}^{3} / \mathrm{h}$, and 178 cored holes, with diameters from 33 to $152 \mathrm{~mm}$, were drilled. A total length of nearly $1100 \mathrm{~m}$ was drilled at rates ranging from $0.4 \mathrm{~m} / \mathrm{h}$ to $1 \mathrm{~m} / \mathrm{h}$, depending on hole size and drilling equipment. Eighteen 610-mm-diam canister emplacement holes were hammer-drilled at an average rate of $1.4 \mathrm{~m} / \mathrm{h}$.

The use of the critical path method, integrated contractors, and close cooperation between project participants facilitated completion of the project on schedule.

\section{INTRODUCTION}

The Spent-Fuel Test in the Climax granitic stock (SFT-C) at the Nevada Test site (NTS) is an ongoing investigation of the feasibility of safe and reliable storage and retrieval of spent-fuel assemblies in a deep geologic medium (Fig. 1; see Ref. 1). The SFT-C is funded through the Nevada Operations Office of the U.S. Department of Energy as part of the National Waste Terminal storage Program. Funding for the project was approved June 2, 


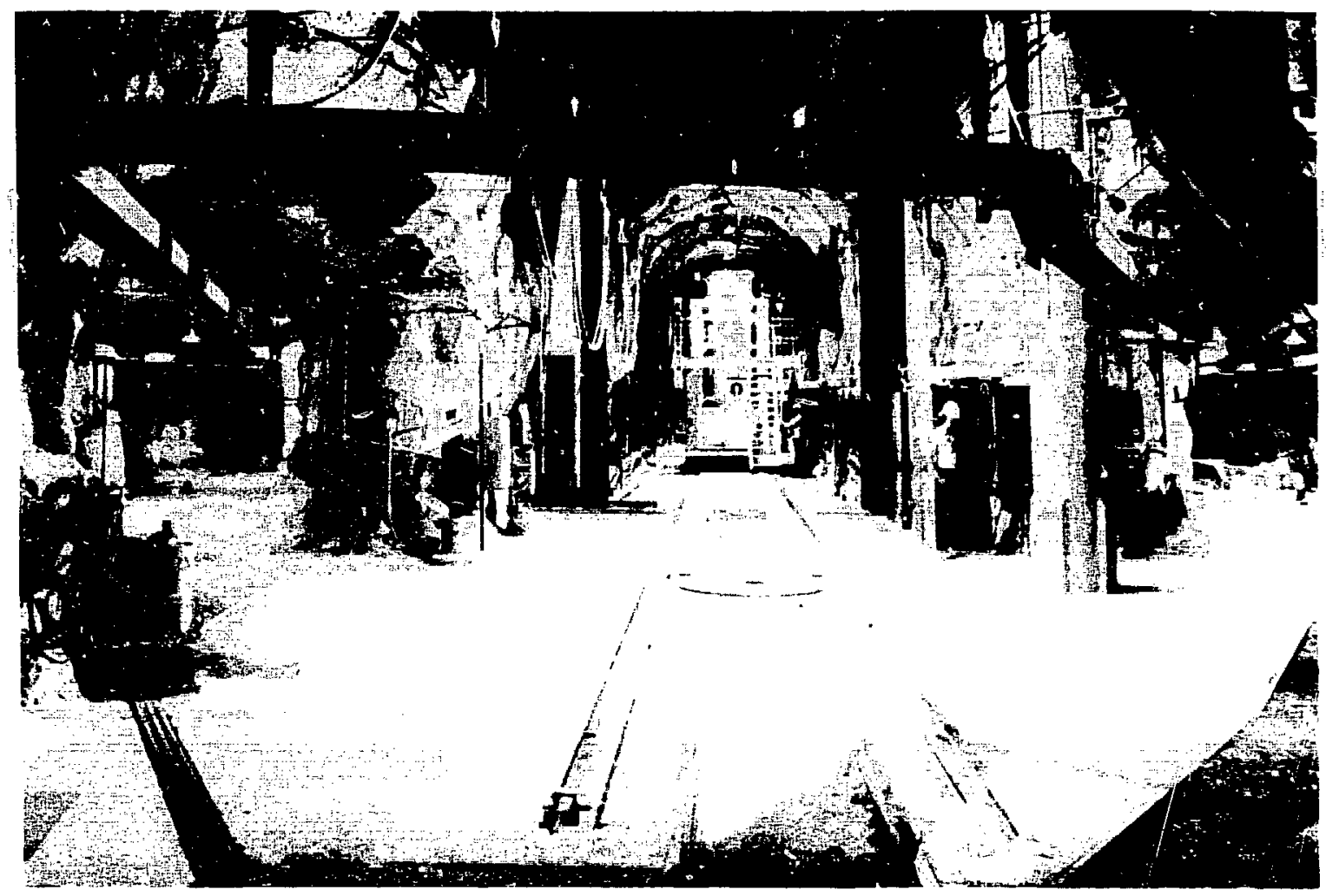

FIG. 1. Panoramic view of SFT-C from the railcar room.

1978 and emplacement of 11 spent-fuel canisters was completed May 28, 1980 at a total emplacement cost of $\$ 18.4$ million.

A principal goal of the test is to demonstrate that spent-fuel assemblies from commercial reactors can be safely and reliably packaged, transported, stored, and retrieved using existing technology. Instrumentation of the test facility will provide data to address technical questions as well. Technical issues are of eqo basic types: in situ response of the granitic medium to combined mechanicil, thermal, and radiation effects; and evaluation of computational techniques for repository design.

This report describes the SFT-C site, its design rationale, and the drilling and mining activities leading to the test emplacenent of spent-fuel canisters. It also documents project constraints. These include site geology, equipment configurations, available facilities, and cost and schedule considerations. Observations and recommendations pertinent to design and construction of hard rock waste repositories or of a test and evaluation facility are also provided. 
To put the subject of this report in perspective, we first examine the portion of total project cost addressed here. The excavation and drilling activities were performed by Reynolds Electrical and Engineering Company (REECO). Table 1 indicates the cost incurred by the major project participants through FYBO.

Costs at Lawrence Livermore National Laboratory (LLNL) include design and construction of the canister handing system, instrumentation, data acquisition system, geological and geotechnical investigations, supporting scoping calculations, and overall technical direction of the test. The REECo costs account for 498 of the total. However, drilling and excavation work orders account for only about $\$ 4.85 \mathrm{M}$ or 268 of the total cost. These are the cost elements discussed in detail in this report. Other REECo costs include refurbishment of the surface plant, utilities, installation of instrumentation and power cables, construction and repair of access roads, surface and underground concrete placement, and numerous other construction and maintenarce activities. Westinghouse Electric Company (W) procured materials for and assembled the canisters, and later encapsulated both the spent-fuel and the electrical simulators. Holmes \& Narver $(H \& N)$ as well as Fenix \& Scisșon (F\& $S$ ) provided $A-E^{\star}$ services for facility design and for drilling and mining, respectively. Total A-E cost is 108 of REECo construction cost.

\footnotetext{
${ }^{\star} \mathrm{A}-\mathrm{E}=$ architectural and engineering.
}

TAELE 1. SFT-C cost by participant through FY-80. (All figures shown here are thousands of dollars.)

\begin{tabular}{|c|c|c|c|c|c|}
\hline & ILNL & REECo & $w^{a}$ & $H \& \mathbf{N}^{\mathbf{b}}$ & $F \& s^{c}$ \\
\hline FY78 & $\$ \quad 225$ & $\mathbf{\$} 706$ & $\$ \quad 200$ & $\$ 49$ & $\$ 37$ \\
\hline FY79 & 2,966 & 6,199 & 1,224 & 447 & 223 \\
\hline FY80 & 3,225 & 2,134 & 570 & 160 & 30 \\
\hline Totals & $\$ 6,416$ & $\$ 9,039$ & $\$ 1,994$ & $\$ 656$ & $\$ 290$ \\
\hline Grand total & $\$ 18,395$ & & & & \\
\hline
\end{tabular}


The SFT-C is being conducted $420 \mathrm{~m}$ below surface in a granitic intrusive known as the climax stock. Since nuclear weapons effects were studied in the stock in the early 1960s, geologic i.sformation was available from cored holes and underground workings. In addition, four NX-size cores were taken to explore the stock in the vicinity of the proposed SFT-C (Fig. 2).

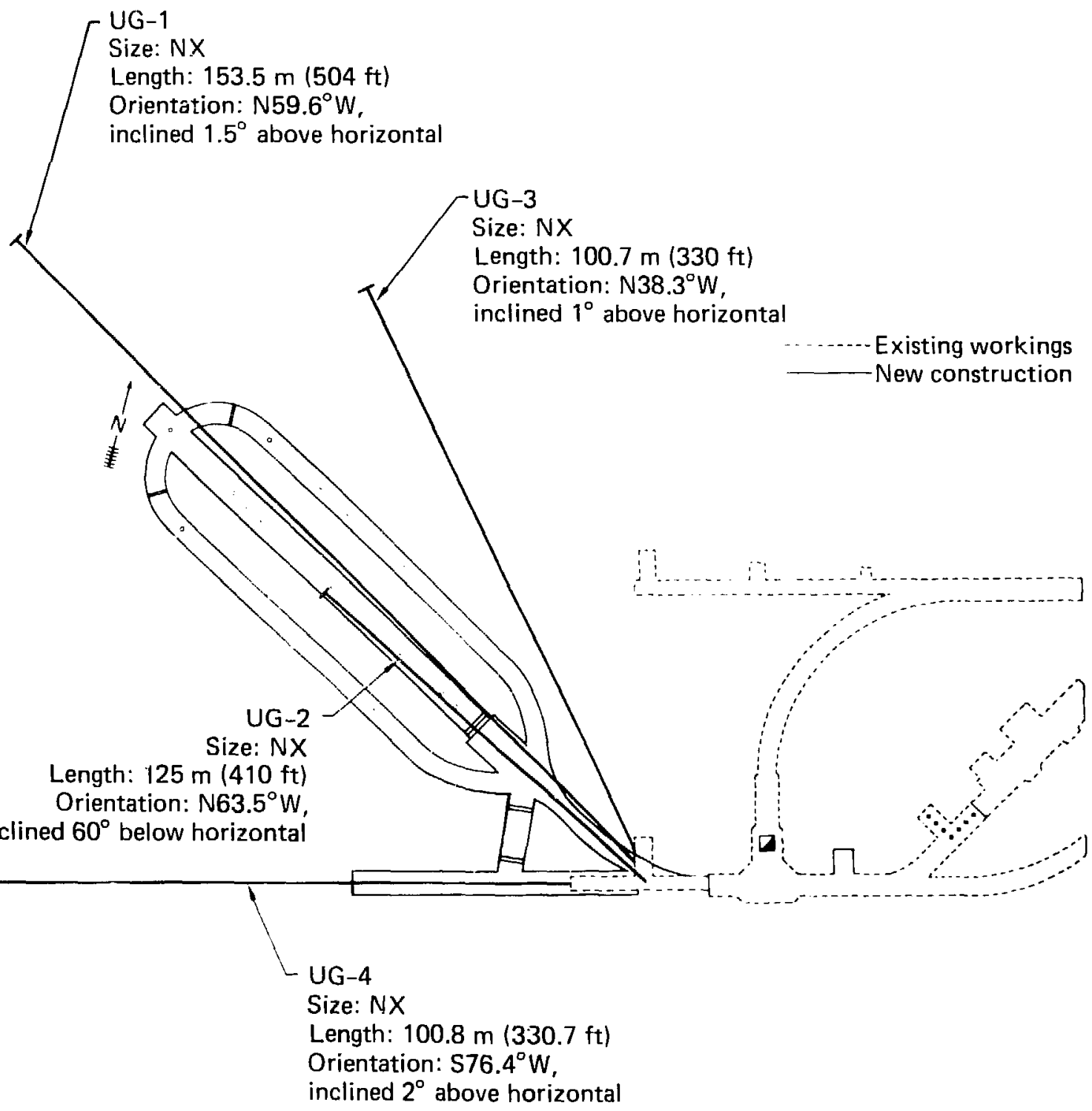

FIG. 2. Preconstruction sxploratory drilling at the SFT-C. 
The stock is composed of two units, granodiorite and quartz monzonite, which contain different proportions of the same minerals. Grain size in both units varies from 1 to $4 \mathrm{~mm}$. The quartz monzonite contains scattered pink alkali feldspar crystals up to $50 \mathrm{~mm}$ long. The SFT-C is located entirely in the quartz monzonite unit. The stock contains numerous fractures and local faults. Nevertheless, relatively unfaulted areas are available for a spentfuel storage test, where jointing does not produce stability problems that would jeopardize retrievability. The most accessible such area is located northwest of the 01501 shaft.

The quartz monzonite of the Climax stock has three predominant joint or ientations of $\mathrm{N} 32^{\circ} \mathrm{W}, 22^{\circ} \mathrm{NE}$; $\mathrm{N} 69^{\circ} \mathrm{W}$, vertical or high-angle; and $\mathrm{N} 35^{\circ} \mathrm{E}, 80$ to $90^{\circ} \mathrm{SE}$. Figures 3 and 4 show joint frequencies for high-angle and low-angle joints, respectively. Joint occurrence averages about three per metre. ${ }^{2}$

In addition to these ubiquitous joints, there are several zones of intense jointing and two faults that intersect the constructed SFT-C (Fig. 5). The fault at the northwest end of the facility is expressed as a 200-to-250-mmthick zone of fractured rock, gouge, and clay. 2

A summary of material properties of the Climax stock matrix, together with typical values for granites and granodiorites, is presented in Table 2. In situ measurements ${ }^{3}$ indicate a modulus of $26 \mathrm{GPa}$ and a Poisson's ratio of 0.246 . The quartz monzonite is a dense, low-porosity rock having high

TABLE 2. Comparison of rock properties.

\begin{tabular}{lll}
\hline Property & $\begin{array}{l}\text { Climax stock } \\
\text { quartz monzonite }\end{array}$ & $\begin{array}{l}\text { Typical granite/ } \\
\text { granodiorite } 8\end{array}$ \\
\hline Dry density & $\begin{array}{l}2.6-2.66 \mathrm{Mg} / \mathrm{m}^{3} \\
(163-166 \mathrm{pcf})\end{array}$ & $\begin{array}{l}2.53-2.67 \mathrm{Mg} / \mathrm{m}^{3} \\
(158-167 \mathrm{pcf})\end{array}$ \\
Porosity (8) & $0.7-1.1$ & $0.44-3.98$ \\
Compressive strength & $210 \mathrm{MPa}$ & $180-260 \mathrm{MPa}$ \\
& $(30,500 \mathrm{psi})$ & $(26,000-38,000 \mathrm{psi})$ \\
Young's modulus & $61.4-69.7 \mathrm{GPa}$ & $30-69 \mathrm{GPa}$ \\
& $\left(8.9-10.1 \times 10^{6} \mathrm{psi}\right)$ & $\left(4.4-10.0 \times 10^{6} \mathrm{psi}\right)$ \\
Poisson's ratio & $0.21-0.22$ & $0.1-0.2$ \\
Thermal conductivity & $3.0 \mathrm{~W} / \mathrm{m} \cdot \mathrm{K}$ & $2.7 \mathrm{~W} / \mathrm{m} \cdot \mathrm{K}$
\end{tabular}




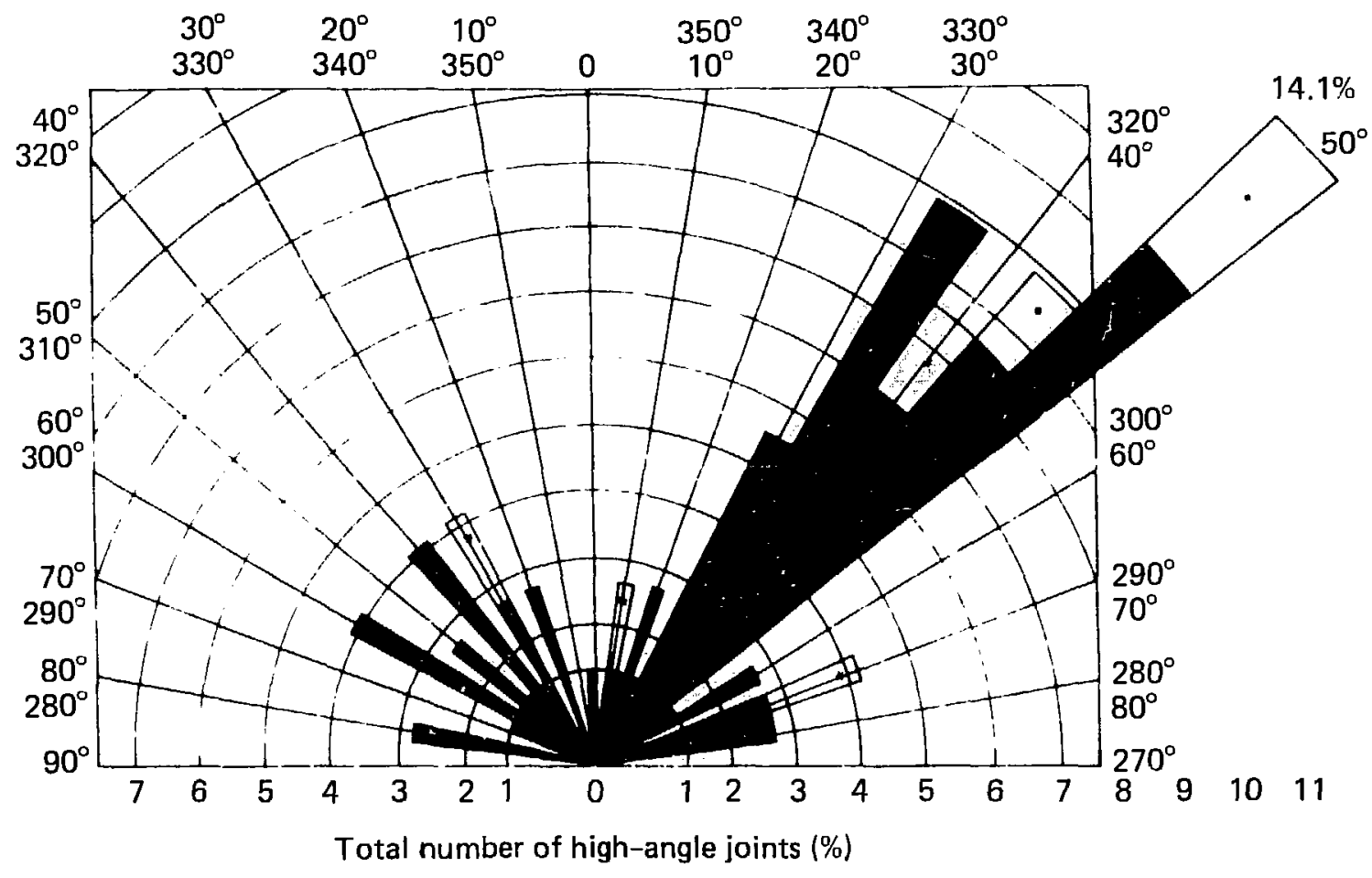

FIG. 3. Relative frequency of occurrence of high-angle joints.

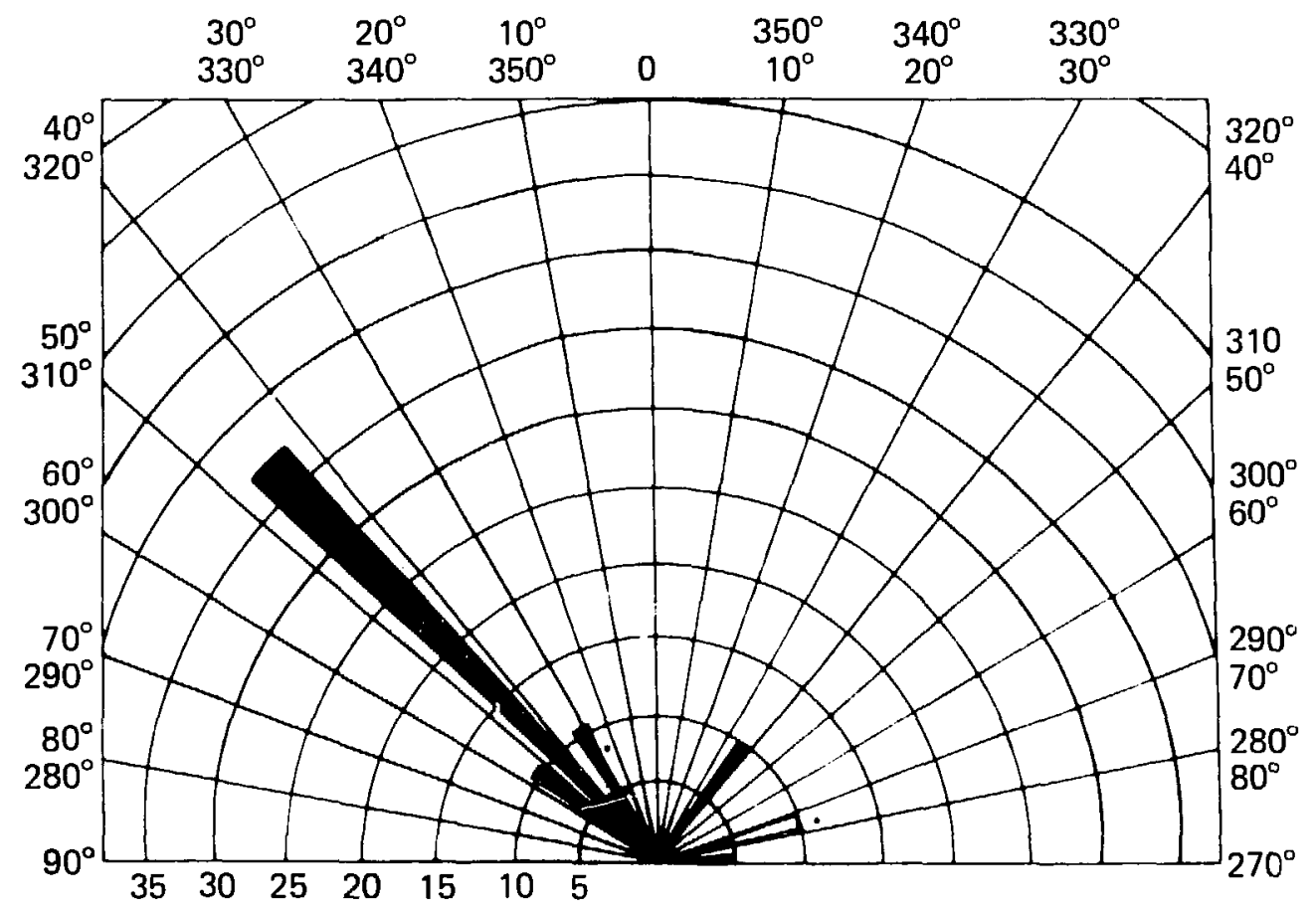

Total number of low-angle joints (\%)

FIG. 4. Relative frequency of occurrence of low-angle joints. 


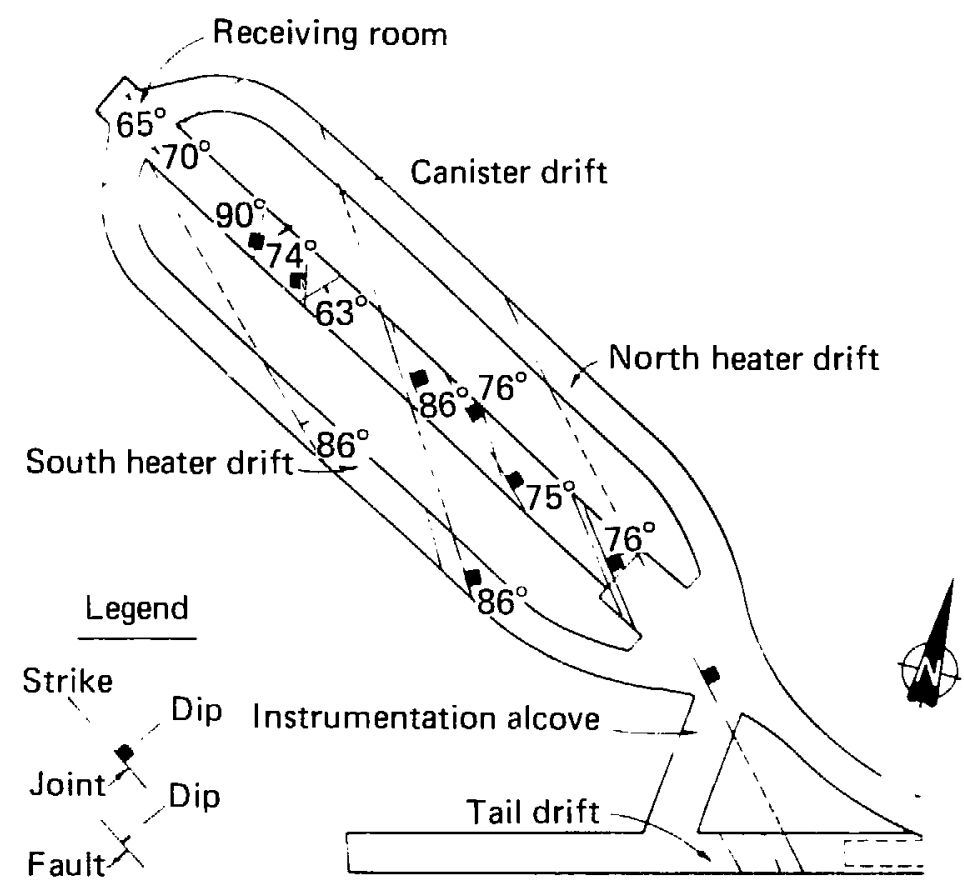

FIG. 5. Locations of shear zones and faults.

strength and modulus. The thermal conductivity--a key factor in waste repository design--is somewhat higher than the average for this rock type.

The in situ state of stress was determined using the stress-relief overcore technique with a three-component USBM borehole deformation gauge. ${ }^{9}$ These values are reported in Table 3 . The vertical component $\left(\sigma_{z}\right)$ is somewhat lower than that calculated using the weight of overburden (10.9 vs $7.92 \mathrm{MPa})$. Examination of data from a hole in which a stress profile was obtained indicates at least some of the data used in these calculations were taken in a block of rock that had been somewhat destressed with respect to surrounding rock. Stress orientations are in good agreement with other measurements near the site.

The test is located above the regional water table and the rock is unsaturated, but not dry. About 1 to 2 wto water is localized in fractures and pores. 
TABLE 3. In situ state of stress at the SFT-C. 9

\begin{tabular}{|c|c|c|c|c|c|}
\hline & Stresses & $\begin{array}{c}\text { Stress } \\
\text { magnitude } \\
{\text { (MPa })^{a}}^{\text {(MPa }}\end{array}$ & $\begin{array}{l}\text { Stress } \\
\text { std dev } \\
\text { (MPa) }\end{array}$ & Bearing & $\begin{array}{c}\text { Inclina:ion } \\
\text { (deg) }\end{array}$ \\
\hline \multirow[t]{4}{*}{ A. } & $\frac{\text { Principal }}{\text { components }}$ & & & & \\
\hline & $s_{1}(\min )$ & +2.75 & \pm 0.65 & $\mathrm{~N} 42^{\circ} \mathrm{W}$ & -14 \\
\hline & $s_{2}(\max )$ & +11.56 & \pm 1.05 & $\mathrm{~N} 56^{\circ} \mathrm{E}$ & -29 \\
\hline & $s_{3}($ interm $)$ & +7.13 & \pm 0.81 & $\mathrm{~N} 26^{\circ} \mathrm{E}$ & $+57^{b}$ \\
\hline \multirow[t]{7}{*}{ B. } & $\begin{array}{l}\text { Normal and shear } \\
\text { Components }\end{array}$ & & & & \\
\hline & $\sigma_{\mathbf{x}}$ (east) & +7.64 & \pm 0.63 & East & Hor izontal \\
\hline & $\sigma_{y}($ nor th $)$ & +5.87 & \pm 0.81 & Nor th & Hor izontal \\
\hline & $\sigma_{\mathrm{z}}($ vertical) & +7.92 & \pm 0.67 & -- & Vertical \\
\hline & $T_{x y}$ & +3.61 & \pm 0.50 & - & - \\
\hline & $\mathrm{T}_{\mathrm{yz}}$ & -0.28 & \pm 0.72 & - & -- \\
\hline & $T_{2 x}$ & -2.24 & \pm 0.54 & -- & - \\
\hline
\end{tabular}

Positive sign on stress denotes compression.

${ }^{b}$ Positive sign on inclination denotes degrees above horizontal.

DESIGN AND CONSTRUCTION CONSTRAINIS

DESCRIPTION OF PACILITY

The layout of the facility is shown in Figs. 6 and 7 . A $3.7 \times 3.7-m$ access drift enters the railcar storage room, which is $14.6 \times 6 \times 7.6 \mathrm{~m} \mathrm{high}$. Beyond this room, the canister storage drift $(6.1 \mathrm{~m}$ high $\times 4.6 \mathrm{~m}$ wide) extends $64 \mathrm{~m}$ to the receiving area at the bottom of a $762 \mathrm{~mm}$ access hole witil a 485-mm-i.d. casing. The spent-fuel canisters were lowered from the surface through this access hole. A set of tracks for the railcar run from the access hole to the railcar storage room. The spent-fuel canisters are stored in a linear array of vertical holes spaced every $3 \mathrm{~m}$ between the rails. 


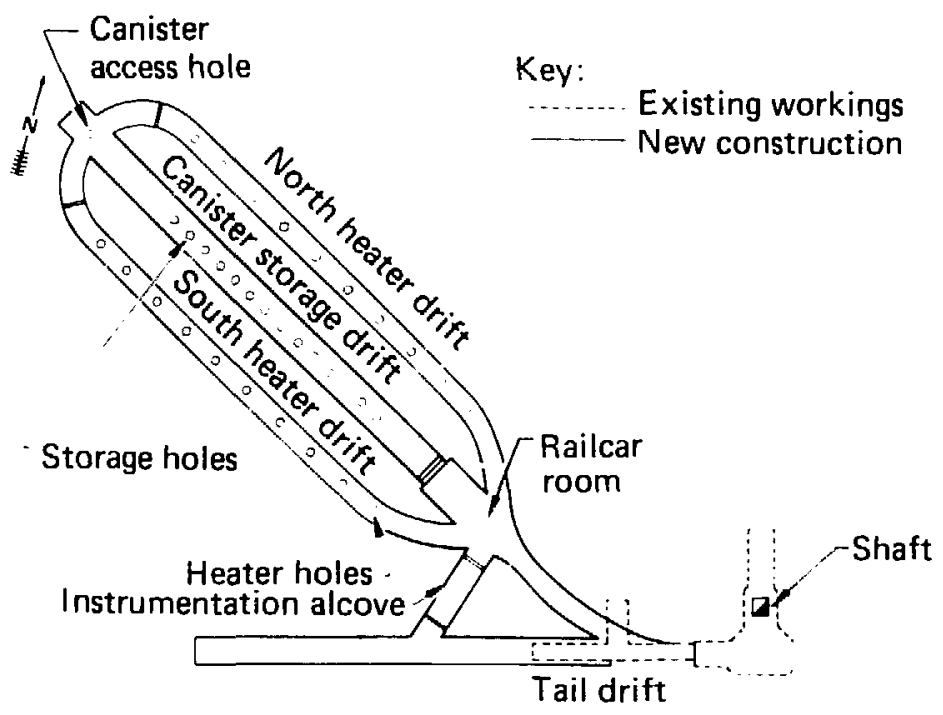

FIG. 6. Plan view showing layout of SFT-C.

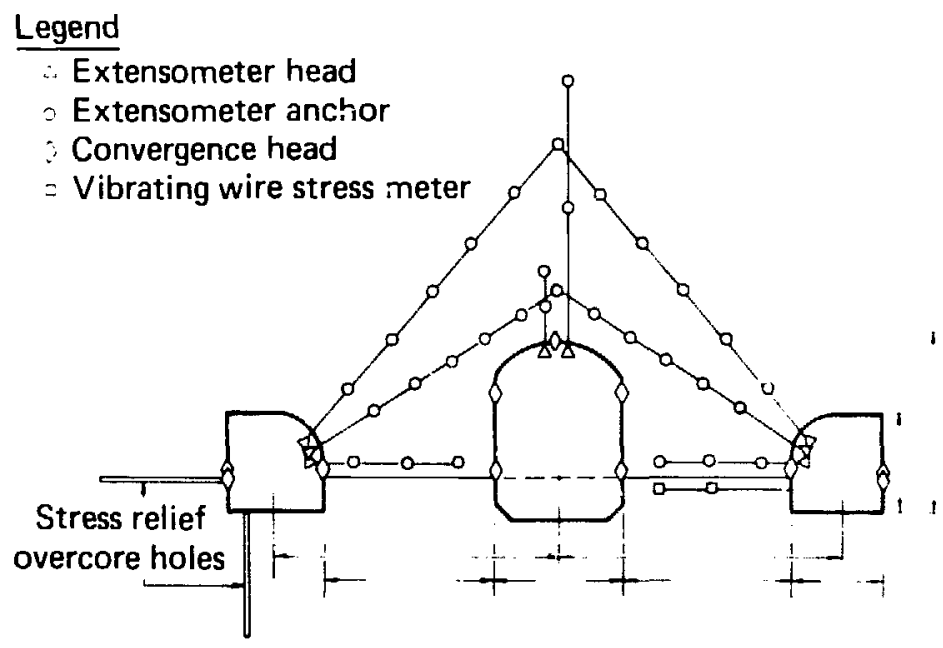

FIG. 7. Schematic cross section of SFT-C showing mine-by geotechnical instrumentation.

A total of 17 storage holes are provided in the canister storage drift. of these, 11 are used for spent fuel, and 6 for electrical simulators. An additioral hole is located in the railcar room and used to store a dumuly canister for training personnel and evaluating handling equipment. The holes themselves are $610 \mathrm{~mm}$ in diameter, with a 457-mm casing, and a 5.2-m depth. Numerous small-diameter holes were drilled to contain thermal, stress, and displacement instrumentation. 
The north and south heater drifts measure $3.4 \times 3.4 \mathrm{~m}$ and have been excavated on either side of and parallel to the canister storage drift. Their spacing of 9.8 and $10.2 \mathrm{~m}$ from the storage drift resulted from adjustment of the storage drift to center on the drilled access hole after the location was verified, following mining of the heater drifts. Electrical resistance heaters with a diameter of approximately $19 \mathrm{~mm}$ were placed in these heater drifts at $6-m$ intervals in small holes in the floor.

\section{CONSTRAINTS}

There were several constraints leading to the design and construction of the SFT-C as described above. Major considerations were the presence of existing facilities, integrated contractors, and DUE ownership of the site. These factors had a beneficial effect on both expediting the schedule and minimizing the cost of constructing the facilities for the test. Existing facilities include a large, shielded structure at NTS, which was used to encapsulate the spent-fuel assemblies into canisters and to load them into a shielded transport vehicle for shipment to the SFT-C site. ${ }^{1,10} \mathrm{Tr}:$ is eliminated the need for a costly shielded structure at the SFT-C site. The site itself had an existing mine surface plant, shaft, and drifts on two levels (including the $420-m$ level of interest) that were used during the early 1960 s in nuclear weapons effects studies. These facilities provided ready access to granitic rock at a plausible repository depth.

Site geology and surface topography were used to select the canister access-shaft location and, hence, the orientation of the underground workings. Tunnel orientation (N61 $W$ ) was selected to be roughly parallel and perpendicular to frequently encountered joint sets. Some adjustment was made in orientation to favorably site the canister access shaft with respect to surface topography.

Canister drift dimensions were dictated primarily by the size of the underground transport vehicle (UTV) used to emplace and retrieve the spentfuel canisters. ${ }^{10}$ The UTV satisfied the requirement for handing the fuel in a fully shielded configuration. Although remote handling is the normal mode of operation, manned operation of the UTV is, thus, possible. Drift dimensions of $6.1 \mathrm{~m}$ high and $4.6 \mathrm{~m}$ wide permitted operation of the remote control UTV with its associated crane assembly, while allowing room for instrumentation and passage of personnel on either side of the vehicle. 
The heater drifts were located to allow simulation of the thermal history of an actual repository. An array of "guard" heaters on either side of the central canister drift was calculated to produce a thermal regime in the vicinity of the five central canisters which closely approximated that in the center of a large repository. 1,11 It was, thus, possible to model repository conditions and measure associated responses on a relatively small scale. Since the guard heaters would be small and somewhid flexible, a smaller drift size $(3.4 \times 3.4 \mathrm{~m})$ was permissible.

All project participants were subjected to a time constraint in the form of the fuel emplacement schedule. This constraint drove the entire project, often producing modifications to subordinate goals and objectives.

The final design consicerations governed the sequence and method of excavation. Location of the shaft (through which spent fuel would be lowered) with respect to the central canister drift was critical. This consideration supported the concept of sinking the canister access shaft, locating it precisely with the heater drifts, and then driving the canister drift to the known shaft location. Furthermore, excavating the side drifts first would permit geologic mapping and installation of instrumentation to assess stability and support requirements prior to excavation of the significantly larger canister drift. Based on these considerations, the canister access shaft was sunk, followed by heater drift excavation. Instrumentation was then installed from the pazter drifts. Finally, the canister drift was excavated in two phases: as a top heading and as a bench. With one exception, contractor personnel had control over selection of the excavation technique and equipment. Smooth-wall blasting was specified (on a "best effort" approach) for two short intervals of the heater drifts where instruments would be located and for the entire canister drift. The modest magnitude of the mining work on this project, in effect, produced a constraint on the equipment selected for mining. Equipment available on NTS or on a lease basis was employed to minimize capital equipment costs. Hard rock mining had not been recently performed at NTS nor was there any hard rock mining of a substantial nature programmed beyond the SFT-C for NTS to amortize expensive full-face mining equipmeit. 
REFURBISHMENT OF THE PERSONNEL SHAFT

The personnel access shaft for the SFT-C was sunk in the early 1960 s to a depth of $244 \mathrm{~m}$ for the Hard Hat nuclear weapon effects test. It was partially stemmed with sand, but nevertheless received considerable damage.

In 1964, the shaft was sunk to the present $420-m$ depth for the Pile Driver nuclear weapon effects test. The shaft was again partially stemmed with sand and was again severely damaged. Remining from the surface down to depth took over seven months. Subsequently, the shaft was used only for occasional tours. During this period the underground workings were not ventilated except during these infrequent trips.

The shaft is nominally $1.8 \times 3.7 \mathrm{~m}$ in cross section and is divided into three compartments. A $1.8 \times 2.6-\mathrm{m}$ hoisting compartment accommodates materials, muck, and personnel. A $1.1 \times 1.2-\mathrm{m}$ ladderway is provided for emergency use in the event of power failure. Ventilation lines pass downward through the third $0.6 \times 1.1 \mathrm{~m}$ compartment.

In 1977, the shaft was opened for moderate use to prepare for and carry out the LLNL-sponsored granite heater experiment. 12 Only minimal repairs were made for this test. Repairs included replacement of several elevator guides and installation of a small telephone cable. Instrument cables were installed in a 150-mm-diam conductor down one corner of the shaft for subsequent remote reading of instruments from the surface.

Upon approva! of funds for the SFT-C, major rebuilding of the shaft was begun. Tris work included virtually complete replacement of the wooden elevator guides necessary during high-speed mucking operations, and constant hauling of men and materials. New ladders and landings were installed in the manway. The twin, 410-mn-diam exhaust lines had corroded through in many places and their roughness caused high head loss. Complete replacement of the ducts was required to meet mine safety requirements for blasting and underground diesel equipment operation. Rotten lagging between steel seis was replaced as necessary. A new primary power cable $(2400 \mathrm{v})$ and phone cable were also installed at this time. 
The location of the canister access shaft was dictated by the orientation of the storage drift layout underground. Two primary choices were developed using an approximately $\mathrm{N} 61^{\circ} \mathrm{W}$ or ientation (described earlier) and the existing tail drift orientation of $576^{\circ} \mathrm{W}$. They were the primary and secondary arrangements most favorable Eor mining and opening stability. Since the hole location for the $576^{\circ} \mathrm{W}$ or ientation was on a rocky hillside requiring expensive development as well as relocation of a high-voltage power line, it was eliminated from consideration.

Corstruction of the $61 \times 61-m \mathrm{drill}$ pad and access road was begun in August 1978 to prepare for an October drilling start. The drill hole diameter of $762 \mathrm{~mm}$ was determined by the 485-mm-i.d., 560-mm-o.d. casing size for passing a spent-fuel canister and its lowering mechanisms. The annular space was required for placement of two 50-mn-diam cementing lines.

The drill rig started the hole using a shop-built, tricone rotary bit with carbide buttons. The mean drilling rate in the granite formation was about $0.24 \mathrm{~m} / \mathrm{h}$ (Table 4 ). Different collar weights and rotation speeds were tested with iittle increase in penetration rate. after drilling this way for $90 \mathrm{~m}$, it was decided to rent an Ingersoll-Rand downhole hammer drill with an on-the-drill weight of about $7000 \mathrm{~kg}$ and a rotation speed of 2 rpm (the

TABLE 4. Drilling statistics for canister-access shaft.

\begin{tabular}{|c|c|c|c|c|}
\hline \multirow[b]{2}{*}{ Drilling parameter } & \multicolumn{2}{|c|}{ Rotary tri-cone } & \multirow[b]{2}{*}{$\begin{array}{l}\text { Hammerdrill } \\
\text { (redrilling) }\end{array}$} & \multirow[b]{2}{*}{$\begin{array}{l}\text { Harmerdrill } \\
\text { (ner: drilling) }\end{array}$} \\
\hline & $\begin{array}{l}\text { Upper } \\
\text { section }\end{array}$ & $\begin{array}{l}\text { Lower } \\
\text { section }\end{array}$ & & \\
\hline Distance drilled (m) & 90.5 & 13.7 & 90.5 & 305 \\
\hline Rotating time (h) & 381 & 68.0 & 37.5 & 201 \\
\hline Mean drilling rate $(\mathrm{m} / \mathrm{h})$ & 0.24 & 0.20 & 2.4 & 1.5 \\
\hline Rig time $(h)^{a}$ & 564 & 88.0 & 73.5 & 616 \\
\hline $\begin{array}{l}\text { Mean effective drilling } \\
\text { rate }(m / h)\end{array}$ & 0.16 & 0.16 & 1.2 & 0.5 \\
\hline
\end{tabular}

${ }^{{ }}$Rig time is total time on the hole excluding approved work stoppages and logging time. 
penetration rate averaged $1.5 \mathrm{~m} / \mathrm{h}$ ). While the hole was open during drill changeover, the first of three directional surveys was taken optically to det-rmine hole drift. Projecting the drift rate to total depth (TD), the planned drift centerline point of intersection (PI) was adjusted.

Drilling continued uneventfully until $315 \mathrm{~m}$ when the hammer drill bit developed an irreparable crack. Before tripping out of the hole, a second directional survey was taken with a sperry-Sun gyro. The hole drift was found to be in the same general direction as determined at $90 \mathrm{~m}$. Drill type did not seem to change this drift, which was oriented approximately $s 35^{\circ} \mathrm{W}$. The steeply dipping rock joints striking roughly perpendicular to the hole drift: were thought to be the cause. Since drift mining had not yet started, another change in planned PI was made to accommodate the projected $3.7-\mathrm{m}$ horizontal offset.

Canister access-hole drilling continued with the new replacement hammer drill bit at the $1.5 \mathrm{~m} / \mathrm{h}$ rate to a depth of $395 \mathrm{~m}$. This bit also cracked beyond repair and was replaced with the original tricone bit since there was no other hammer drill bit available. The remaining $14 \mathrm{~m}$ was $\mathrm{drilled}$ at about $0.2 \mathrm{~m} / \mathrm{h}$.

As indicated by the mean drilling rates, the hamner drill provided a substantial increase in penetration. The six-to-eight-fold increase noted so far in this discussion is based on rotating time. If the effective drilling rate is calculated using the $r i g$ time as defined in Table 4 , the improvement in arilling rate is reduced somewhat to about three-fold better. This is a reflection of the greater downtime associated with the hammer drill operating in the hard, abrasive Climax quartz monzonite. Use of such a drill in softer, less abrasive materials should produce even better results.

At thi: time total depth was reached, mining was starting on the railcar room and the heater drifts. Since the horizontal drift of the access hole was perpendicular to the Spent-Fuel Test array, an extremely accurate directional survey was required. Three gyrodirectional logs were made, logging on both the down and up trips, with an effective shot spacing of $1.5 \mathrm{~m}$. Using a computer code developed at LLNL earlier to precisely locate postshot drilling for underground nuclear tests, a TD coorcinate with a possible error circle of $150 \mathrm{~mm}$ was computed.

An optical survey was also run down to a depth of $305 \mathrm{~m}$ where line of site ended. With good agreement from both surveys, the bearing of the canistor drift was changed to $N 61^{\circ} 15 ' W$ to intercept the access hole. The accuracy of 
the survey was verified when the heater drifts hit the drill hole less than $150 \mathrm{~mm}$ from the predicted location. Total hole deviation was $4.92 \mathrm{~m}(\sim 1.28)$. This deviation, which included a "dog leg", required modification of the grapple brake assembly on the canister lowering system.

Subsequent to directional surveying, the hole was washed, bailed, and photographed, and a density $\log$ was obtained. The $140 \mathrm{~kg} / \mathrm{m}(94 \mathrm{lb} / \mathrm{ft})$, 508-mm-o.d. casing was lowered and cemented with Type A cement with a 28 calcium chloride additive.

UNDERGROUND DEVELOPMENT

Underground development began with the drilling of four NX-size (76-mm-diam) exploratory holes with a Longyear 44 coring $r i g$ from an existing drift west of the main 1501 shaft (Fig. 2). Three of the borings are nearly horizontal and explore the regions north and south of the SFT-C as well as the region along the central axis of the SFT-C. The fourth boring probes the region below the facility. A total of $480 \mathrm{~m}$ was drilled with about 998 core recovery. Drilling rates averaged about $1 \mathrm{~m} / \mathrm{h}$ for this operation. All cores were logged and photographed for record. Sections of these cores were then used to determine laboratory values of mechanical, hydrological, ar 1 tinermal properties. Joint frequencies zere observed, but since the cores were not oriented, joint orientations were not obtained. No indications of faulting or zones of intense jointing were observed, although an alteration zone (later found to coincide with the receiving room fault) was logged.

Excavation was accomplished using $\mathrm{Jr}$ ill-and-blast techniques to fragment the rock and a load-haul-dump unit to move the rock to the hoist station. Four types of drills were employed. Two Atlas-Copco 205 "Miniboomers" were used to drill blast holes in the tail drift, the spur leading to the canister drift, and the two heater drifts (Fig. 1). These are two-boom rotary percussion units. A four-boom, shop-built jumbo was employed in the top heading of the canister drift. Four Gardner-Denver RP 123 rotary percussion machines were mounted on this jumbo. A Leroi airtrack was used to drill the bench of the canister drift. Gardner-Denver sinkers were also used in the benching operation. Sinkers were employed where access was limited, to enlarge rooms, and to facilitate secondary breakage of oversize material. Most mucking was accomplished with an EIMCO 913. An EIMCO 630 was available for use on small jobs and in restricted access areas. 
Excavation of the short section of drift leading to the bifurcation of the two heater drifts bregan when sinking of the canister access shaft was nearly completed. The heater drifts were then excavated.

Almost inmediately probiems were encountered in the mining operation. Difficulties in excavating were observed to be due to several causes.

1. Jcinting produced a blocky structure along which breakage occurred, producing a significant fraction of oversize material. This required secondary breakage, usually by mechanical means.

2. The most recent experience of many of the miners had been in tunneling in tuff, a much softer rock. As a result of this experience, they selected too few holes for the blasting pattern and applied too much thrust to the drill steel. The former problem led to failure to break the rock to the full depth of drilling and to production of oversize material. The latter produced excessive bit wear and broken drill steel.

3. Drill selection was not optimum. The units used to drive the heater drifts could not easily be positioned accuratcly, which led the perimeter holes to be nonparallel and angled outward too much. In the canister drift, an outmoded unit incapable of full-face driving was employed. Here, too, hole alignment was a problem. The two-heading approach using vertical drilling in the bench led to overbreak in the invert as well. The latter effect was due in large part to the presence of joints dipping 20 to $25^{\circ}$ below horizontal, along which fracturu occurred preferentially (Fig. 8).

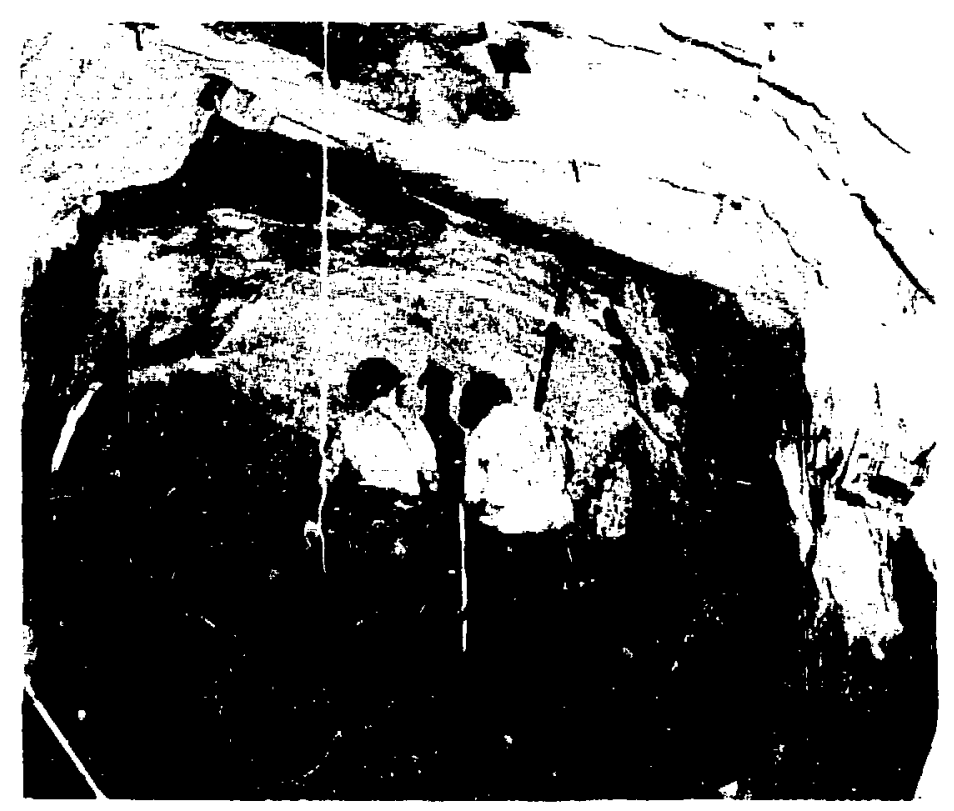

FIG. 8. Section of heater drift showing influence of low-angle joints on excavation. 
4. Steming material was not used. Since stemming was not used, adequate confinement of charges was not obtained. The effect of this omission became even more pronounced where smooth-wall blasting was attempted.

5. Delay patterns were not appropriately emplaced. Again, the critical nature of proper delays was accentuated in the smooth-wall sections where the requirement of simultaneous detonation of the perimeter holes is essential.

Problem areas 2 and 5 were addressed directly. The resulting closer spacing and improved delay pattern also reduced the effects of geology expressed as problem 1. Since the project was of short duration, no attempts were made to alter or replace equipment. Stemming material was never incorporated in the excavation program because contractor personnel did not feel it was important.

Lespite continuing inaccurate hole placement and lack of stemming in holes, smooth-wall excavation was attempted. A fairly standard round was selected and in use by the time about half of the heater drift excavation was completed (Fig. 9).

The canister drift was excavated in two headings due to unavailability of full-face tunneling equipinenc. A standard round was developed and used throughout excavation of the top heading of the canister drift (Fig. 10). Results were adequate with an even contour being produced in the crown and part

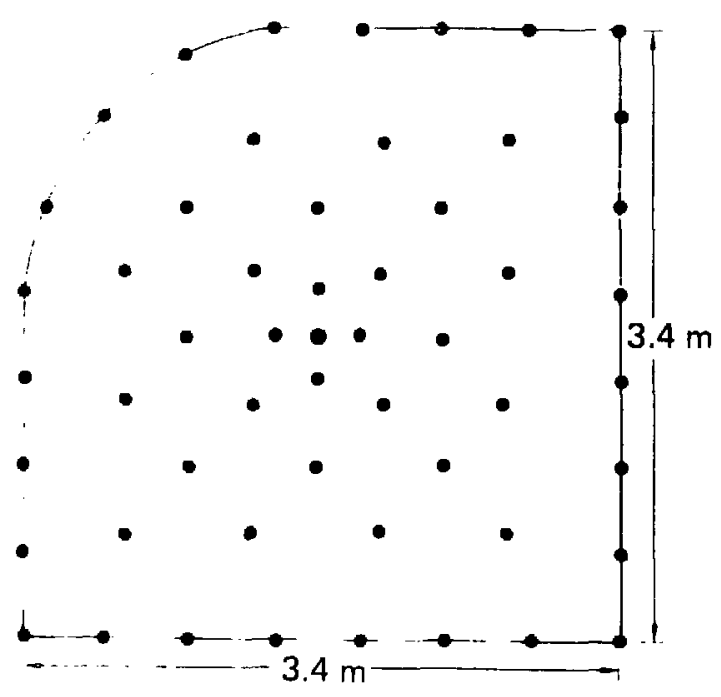

FIG. 9. Burn-cut blast hole pattern for heater drift excavation.

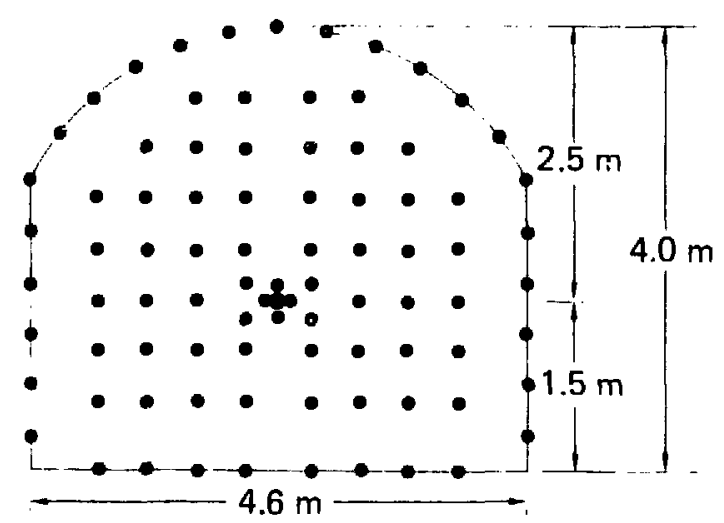

FIG. 10. Burn-cut blast hole pattern for excavation of top heading of canister drift. 
way down the ribs (Fig. 11). Although the specified criterion of keeping overbreak to less than 76 mul was not achieved, perimeter holes were detonated within less than $1 \mathrm{~m}$ of borehole extensometers without producing discernable damage to these units. 13

Construction of the canister drift was completed by excavating the bench using vertical drill holes. This approach provided poor results for two reasons. First, holes were short, about 2 to $2.5 \mathrm{~m}$, so rock of ten remained unbroken at the toe of the bench. Typical mining practice calls for tall benches to avoid this problem. Second, the presence of low-angle joints coupled with the short bench height produced a sawtooth profile in the invert. This led to greater quantities of concrete being used in the floor. Fullface tunneling would have avoided these problem areas and probably would have led to more rapid excavation.

Several minor excavation.s followed completion of the heater drifts and canister drift. The railcar room and receiving room were excavated to the required dimensions with slabbing rounds. The instrumentation alcove was excavated and a tail drift was extended (Fig. 6). Extension of the tail drift was accomplished to preserve the option of executing rock merhanics tests at the site. The tail drift was extended to where future excavation would not damage equipment in the instrumentation alcove.

Excavation rates varied considerably depending on drift cross section, equipment, materials, and excavation method employed. Table 5 shows the

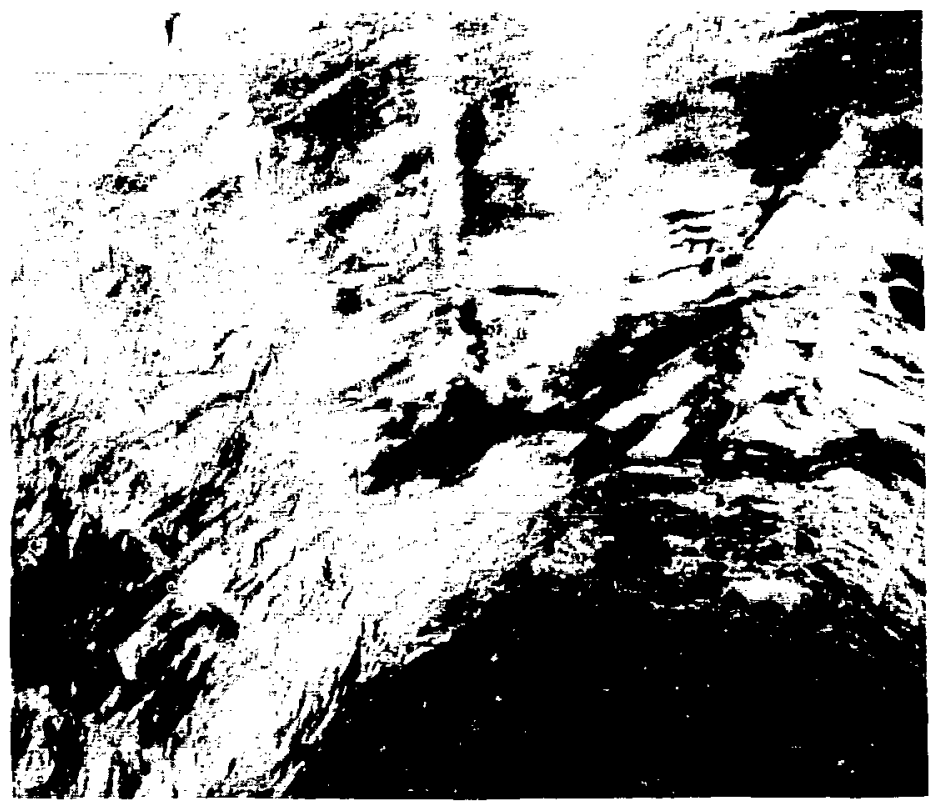

FIG, 11. Typical section of canister drift crown showing results of smoothwall blasting. 
TABLE 5. Excavation rates at the SFT-C.

\begin{tabular}{lcc}
\hline \multicolumn{1}{c}{ Location } & $\begin{array}{c}\text { Cross section } \\
(\max )\end{array}$ & $\begin{array}{r}\text { Excavation rate } \\
\left(\mathrm{m}^{3} / \mathrm{h}\right)\end{array}$ \\
\hline Tail drift & $3.6 \times 3.6$ & 2.0 \\
Canister drift spur & $3.6 \times 3.6$ & 1.8 \\
N. heater drift & $3.4 \times 3.4$ & 1.9 \\
S. heater drift & $3.4 \times 3.4$ & 1.7 \\
Can. drift heading & $4.1 \times 4.6$ & 3.6 \\
Can. drift bench & $2.1 \times 4.6$ & 1.5 \\
Average & -- & 2.0 \\
\hline
\end{tabular}

effects of several of these variables. Rates were slightly greater in the tail drift and canister drift spur than in the smaller heater drifts. Excavation rates in the canister drift heading were nearly double the rates in smaller drifts due to use of a larger jumbo. The effect of excavation technique is seen by comparing the rates in the canister drift heading and bench. The short bench height resulted in inefficient excavation (about 758 of the average) as well as poor fragmentation and overbreak, as noted above.

The excavation rates presented in Table 5 compare quite well with mining industry data for low productivity methods. Most stoping techniques range from a low of $1.1 \mathrm{~m}^{3} / \mathrm{h}$ for shrinkage stoping to over $7.2 \mathrm{~m}^{3} / \mathrm{h}$ for room and pillar stoping. 14 Low productivity methods typically average less than $2 \mathrm{~m}^{3} / \mathrm{h}$. Comparison with tunneling operations is less favorable. Recent European tunneling experience reports excavation rates in granite at 3.6 and $4.5 \mathrm{~m}^{3} / \mathrm{h}$ for a tunnel boring machine and for drill and blast methods, respectively. 15

Several types of explosives were used in the excavation. Hercules "Unigel 65\%" or DuPont "Tovex" were employed in the main round, while Hercules "Hercosplit" or DuPont "Trimtex" were employed in the perimeter holes. Because four types of explosives were available, explosive types were mixed within some of the rounds. Surveillance by $F \& S$ inspectors and REECo supervisors alleviated this problem. All blast rounds were detonated with a nonelectric system utilizing long-period delays downhole. Use of long-period delays is believed to have contributed to the poor results in smooth-wall blasting. 
TABLE 6. Explosive consumption for excavation of SFT-C.

\begin{tabular}{lcc}
\hline \multicolumn{1}{c}{ Location } & $\begin{array}{c}\text { Cross section } \\
(\max )\end{array}$ & $\begin{array}{c}\text { Powder consumption } \\
\left(\mathrm{kg} / \mathrm{m}^{3}\right)\end{array}$ \\
\hline N. heater drift & $3.4 \times 3.4$ & 5.7 \\
S. heater drift & $3.4 \times 3.4$ & 6.2 \\
Canister drift heading & $4.1 \times 4.6$ & 4.0 \\
Canister drift bench & $2.1 \times 4.6$ & 1.8 \\
Average & -- & 5.0 \\
\hline
\end{tabular}

Millisecond delays generally provide detonations more nearly simultaneous within a given delay, due to smaller variations in detonation time.

Explosive consumption also varied considerably with changes in drift dimensions. Table 6 indicates that powder consumption was about one-third less for the canister drift top heading than for the heater drifts. The beneficial effect of two free faces, rather than one, is seen when comparing the explosives consumption for the bench $\left(1.8 \mathrm{~kg} / \mathrm{m}^{3}\right)$ with that for the heading $\left(4.0 \mathrm{~kg} / \mathrm{m}^{3}\right)$. Average explosive consumption in strong rock ranges from 3 to $5 \mathrm{~kg} / \mathrm{m}^{3}$ in tunnels having similar cross sections. ${ }^{14}$ values as large as $6 \mathrm{~kg} / \mathrm{m}^{3}$ have been reported. 14

ROCK SUPPORT

Inspection of existing workings and exploratory cores indicated that the rock was strong and that openings of at least $16 \mathrm{~m}^{2}$ would remain open for a relatively long period with minimal rock bolting as support. There is little experience with the response of rock to heating such as will occur in this test so wire mesh was placed on the drift crowns to support any loose material that may work free during heating and subsequent cooling of the rock. Wire mesh was later found necessary to support loose material generated by excavation activities. A rock that fell from out of the face caused serious injury to an employee early in the excavation process. This led to extending the wire mesh down the ribs of the drifts, although such support would not have prevented the accident.

Ground control measures employed in the drifts and railcar room are as shown in Fig. 12. The type and quantity of rock support were determined by 


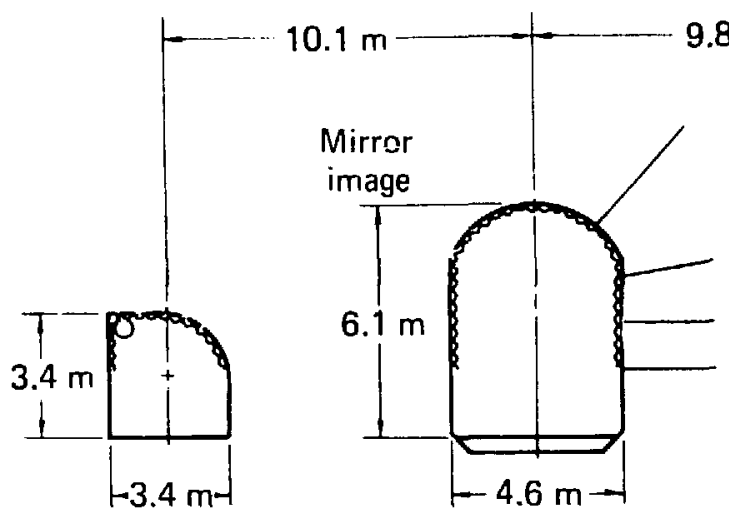

South heater

Canister storage

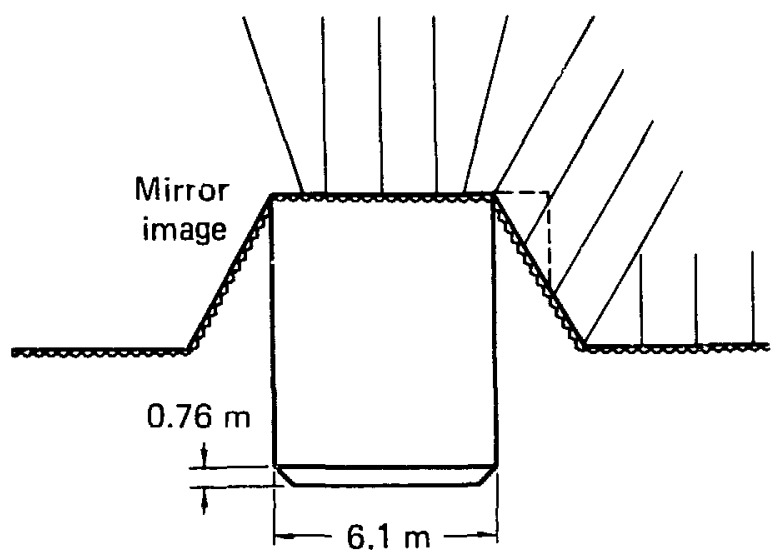

Railcar room

$1.8-\mathrm{m}$ bolts on $1.5-\mathrm{m}$ centers in heater drifts

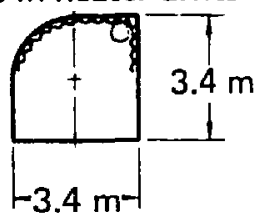

North heater

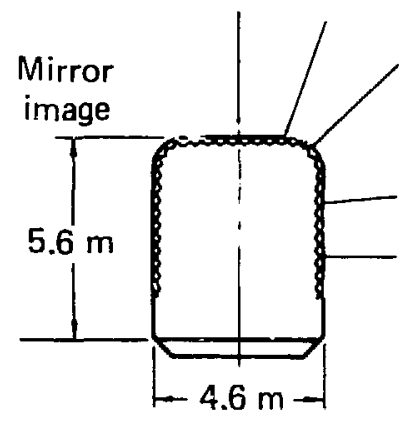

Receiving room

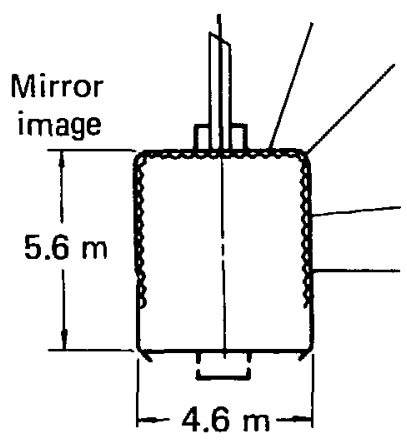

At access hole

FIG. 12. Ground support deployed in the SFT-C drifts and rooms.

opening dimensions, geology, and consineration of whether the support would carry external loads in addition to the rock load. Bolts $1.8 \mathrm{~m}$ long $\times 19 \mathrm{~mm}$ diam or $2.4 \mathrm{~m}$ long $\times 22 \mathrm{~mm}$ diam were installed in the heater drifts, tail drift, and canister drift spur. These bolts were point-anchored with two to three tubes of commercial polyester resin. Subsequent to installation, wire mesh with 50-mm square openings was placed over the bolts, plates were attached, and nuts were tightened. An air impact hammer was used to tension the bolts, but no torque measurements were made. A mean bolt spacing of $1.5 \mathrm{~m}$ was employed across the crown and part way down the ribs of the drifts. Larger cross sections, such as the canister drift and canister receiving room, required longer bolts. In these areas, bolts $3.6 \mathrm{~m}$ long $\times 22 \mathrm{~mm}$ diam were used in the crown and bolts $2.4 \mathrm{~m}$ long $\times 22 \mathrm{~mm}$ diam were used part way down the ribs. Once again, wire mesh was employed to secure loose rock fragments. 
The railcar room is located at the trifurcation of the canister and heater drifts, thus producing a room up to $15 \mathrm{~m}$ wide $\times 13 \mathrm{~m}$ long $\times 7.5 \mathrm{~m}$ high. Bolts $4.9 \mathrm{~m}$ long $\times 28 \mathrm{~mm}$ diameter were full-column anchored in place with an inorganic cement grout. Plates and nuts were installed and tensioned to secure the wire mesh to the rock. The 4.9-m-long units were installed in the crown, while 2.4-m-long point-anchored bolts were emplaced in the brow (Fig. 12).

Some bolts were required to support external loads as well as rock-induced loads. Typical application of these bolts was to support lifting fixtures used during equipment fabrication and operation. All such bolts were pull tested to $3600 \mathrm{~kg}$ with a hollow core hydraulic jack. 'the tested units were color-coded blue to identify them for later use.

FITTING OF CANISTER DRIFT WITH PITS, RAILS, AID CONCRETE

After mining activities were coinpleted, the invert of the canister drift was thoroughly cleaned prior to placing the storage hole pits and reinforcing bars (Fig. 13). Considerable care was taken in locating these pit cans since no lateral adjustments could be made by the railcar. In addition, the cask on the UTV was only 25 mn smaller in diameter than the pit because of shielding

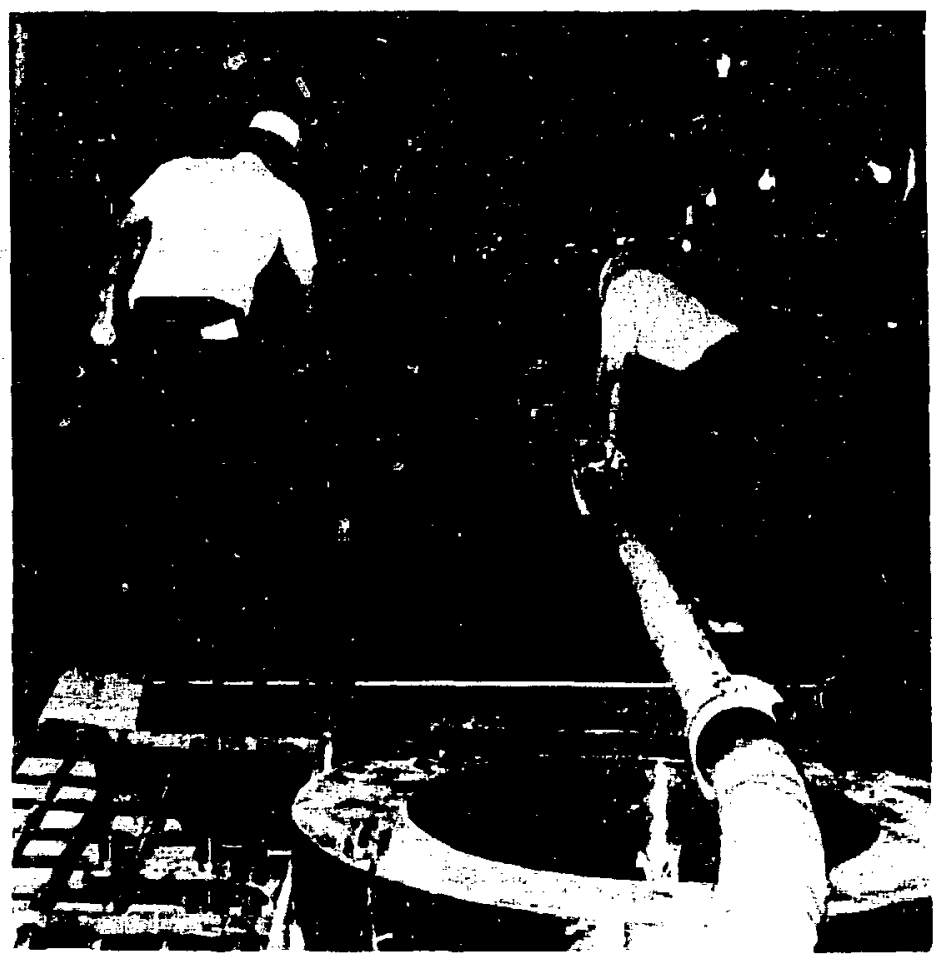

FIG. 13. Canister drift invert ready for concrete pour, showing pit cans and reinforcing bar. 
considerations. Continuous survey control was maintained during the first concrete pouring to detect anci correct lateral movement caused by flotation of the pit cans. The 4l-kg (90-1b) ASCE track rails were set on anchor bolts cast into the first pour. These were located to within $0.8 \mathrm{~mm}$ of the desired distance from pit centerline to ensure proper pit-to-cask fit. The final 150-mu pour encased the rail and was carefully screened and troweled to provide good drainage on the $1 / 28$ grade (Fig. 14).

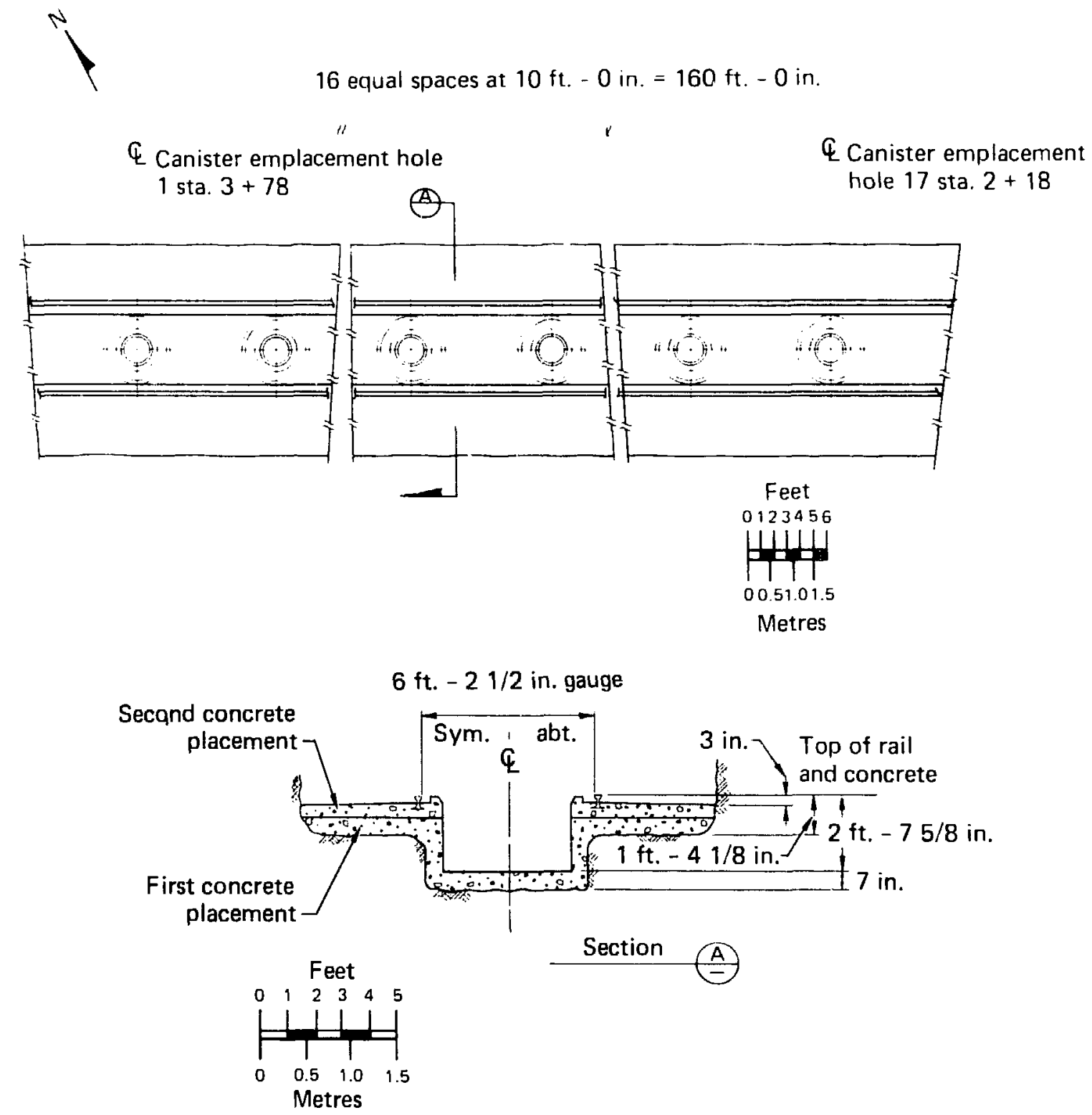

16 equal spaces at $10 \mathrm{ft} .-0 \mathrm{in} .=160 \mathrm{ft} .-0 \mathrm{in}$.

FIG. 14. Canister storage drift configuration before drilling canister emplacement holes. 
Four different methods were investigated for drilling the canister emplacement holes, which were $610 \mathrm{~mm}$ in diameter and $5.2 \mathrm{~m}$ deep.

1. Blind hole rotary drilling uses a system of roller cone bits. The drill setup is similar to raise drilling, but there is no filot hole and thrust is applied downward. A drill manufacturer suggested several types that were either too expensive or for which there was no experience in a granite formation. Previous experience of low penetration using roller cone drilling for the access hole also argued against using this technique.

2. Line drilling requires drilling 20 to 30 overlapping, small-diameter holes in a circular pattern around the periphery of the planned hole. The precision drilling equipment and personnel required for this task were not available.

3. Core drilling with a 560-mm-diam core bit was actualiy tested in the heater test alcove left from an earlier experiment. ${ }^{12}$ slow progress was made due to rig breakdowns, excessive bit wear, and the difficulty of removing large core, which forced suspension of this method after drilling $2.1 \mathrm{~m}$ in the test section.

4. Hammer drilling with a 610-mm-diam Ingersoll-Rand downhole hammer, similar to that used on the 426-m-deep canister-access hole, was selected based on the earlier succuss. A shop-built crawler mounted unit, owned and operated by New Jersey Drilling Company, was chosen for use on the project. While mobilization, demobilization, and rental costs were high, the rapid drill rate and quick setup time proved very economical. Hole-to-hole cycle time was such that two holes per day were completed with a maximum penetration rate of $2.3 \mathrm{~m} / \mathrm{h}$. Average drilling rate was about $1.4 \mathrm{~m} / \mathrm{h}$, including setup time.

The action of the downhole hammer drill is quite similar to smalldiameter rock drills except that percussion is induced within the drili-bit body. The bit cutting face is studded with carbide buttons. The cuttings produced are dry and circulate up to a rubber packer above the hole collar and out a tangential discharge pipe. The cuttings were carried by armored hose to a bulkheaded section of one of the side heater drifts. An exhaust fan line connected to the section carried away all suspended dust. A small amount of dust leakage around the packer made it mandatory to wear special masks when working at or downwind of the machine. 
Drilling speed is dependent on flow and pressure of the air usea to flush the cuttings. Adecuate air supply was maintained by using five $1530-\mathrm{m}^{3} / \mathrm{h}$ diesel compressors at the surfacc, which were connected to the cased canister-access hole. The hole served as a large receiver and conductor pipe.

A record core $75 \mathrm{~mm}$ in diameter was drilled the full length of each proposed emplacement hole prior to the hammer drilling operation. These cores, taken just inside the perimeter of each emplacement hole, will be compared with post-test cores taken just outside the perimeter of each emplacement hole. The two sets of cores will facilitate evaluation of changes in rock characteristics due to the intense thermal and radiation fields imposed on the emplacement hole walls. A core sample, to be used to evaluate drilling-induced rock damage, was taken along the sidewall of the practice hole with a 152-mm-diam bit. This evaluation will help in differentiating between sidewall storage hole damage caused by drilling and that caused by thermal and radislogical exposure.

Each canister drift storage hole was photographed using a fish-eye lens before installing the liner. The storage hole liners furnished by Westinghouse were installed in the 18 holes and grouted at the top and bottom. The grouted sections of the liners were wrapped with sheet metzl sleeves to allow for posttest lirer removal and subsequent sidewall evaluation. Grouting the lower portion of the emplacement holes was straightforward. Several techniques were examined, however, for isolating grout in the upper section of the annulus between the emplacement-hole liners and the wall rock. The simplest and most i ikely to succeed alternative was to emplace and inflate a rotorcycle innertube at the appropriate depth in the annulus. A test using pieces of 508-mm and 610-mm casing indicated that a 2.75/3.00 × 19-in. motorcycle tube inflated to about $70 \mathrm{kPa}$ was effective in isolating the upper from the lower annular space along the length of the liner. This system was used effectively in the field with only one minor incident of leakage. The grout itself was formulated by Holmes \& Narver $(H \& N$ Grout Mix No. 76-1G) to be shrink-compensating and thus minimize potential radiation shine paths.

The 20 side drift heater holes (10 in each drift) were drilled down $1.21 \mathrm{~m}$ with a 76-mun core bit and then continued $4.9 \mathrm{~m}$ deeper with a $51 \mathrm{~mm}$ bit. The difference in diameters provided a shoulder for the heating elements to rest on. A post-mounted CP-65 core drill was used for these holes. One heater hole was drilled per day giving an average drilling rate of about $0.76 \mathrm{~m} / \mathrm{h}$ for a one-shift operation. 
The mine-by instrumentation holes in both heater arifts were orilled by a Joy 22 core drill. These 76-mu-diam holes were drilled at an average rate of about $0.43 \mathrm{~m} / \mathrm{h}$. The instrumentation holes in the canister storage drift were drilled with a Longyear 44 core drill mounted on a turret, attached to a railcar. To position the drill, the railcar was rolled to a hole location and the turret rotated over the collar. This shop-built rig allowed quick and easy drill movement from hole to hole. Drilling rates ranged from $1.1 \mathrm{~m} / \mathrm{h}$ for

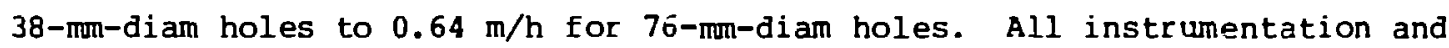
heater holes, with the exception of $63 \mathrm{~mm}$ holes for an acoustic emissions stujy, were cored to evaluate the adjacent rock, to aid in mapping joints and fractures throughout the test area, and to ensure proper anchorage of the instruments. All holes drilled for the entire test were carefully surveyed by an optical line-of-site method to accurately determine the location of the hole bottom.

DESCRIPTION OF SUPPORTING FACILITIES

INSTRUMENTATION

Simplistic, finite-element scoping calculations indicated that rock in the region surrounding the three-drift array would be elastically displaced into the openings as a result of mining these arifts. ${ }^{l}$ The response of rock surrounding the canister drift could be monitored using an array of instrumentation (placed from the heater drifts before the canister drift was mined [Fig. 7]). Multiple-point borehole and tape extensometers were used to measure relative displacements. Vibrating wire stress meters were employed to record stress changes. All instrumentation was located in accordance with the computer calculations of relative displacements and stress changes. Individual anchors of the multiple-point extensometers were located to include zones of highly fractured as well as relatively unfractured rock. The relatively low priority of instrumentation imposed rigid schedule constraints on assembly and installation. The instrumentation plan was executed so that there would be no negative impact on excavation. Measurements of small, relative displacements and stress changes due to mining indicated a stable excavation. 2

After completion of major excavation and construction activities, the full suite of instrumentation to be employed during the spent-Fuel Test ${ }^{16}$ was installed (Figs. 15 and 16). 


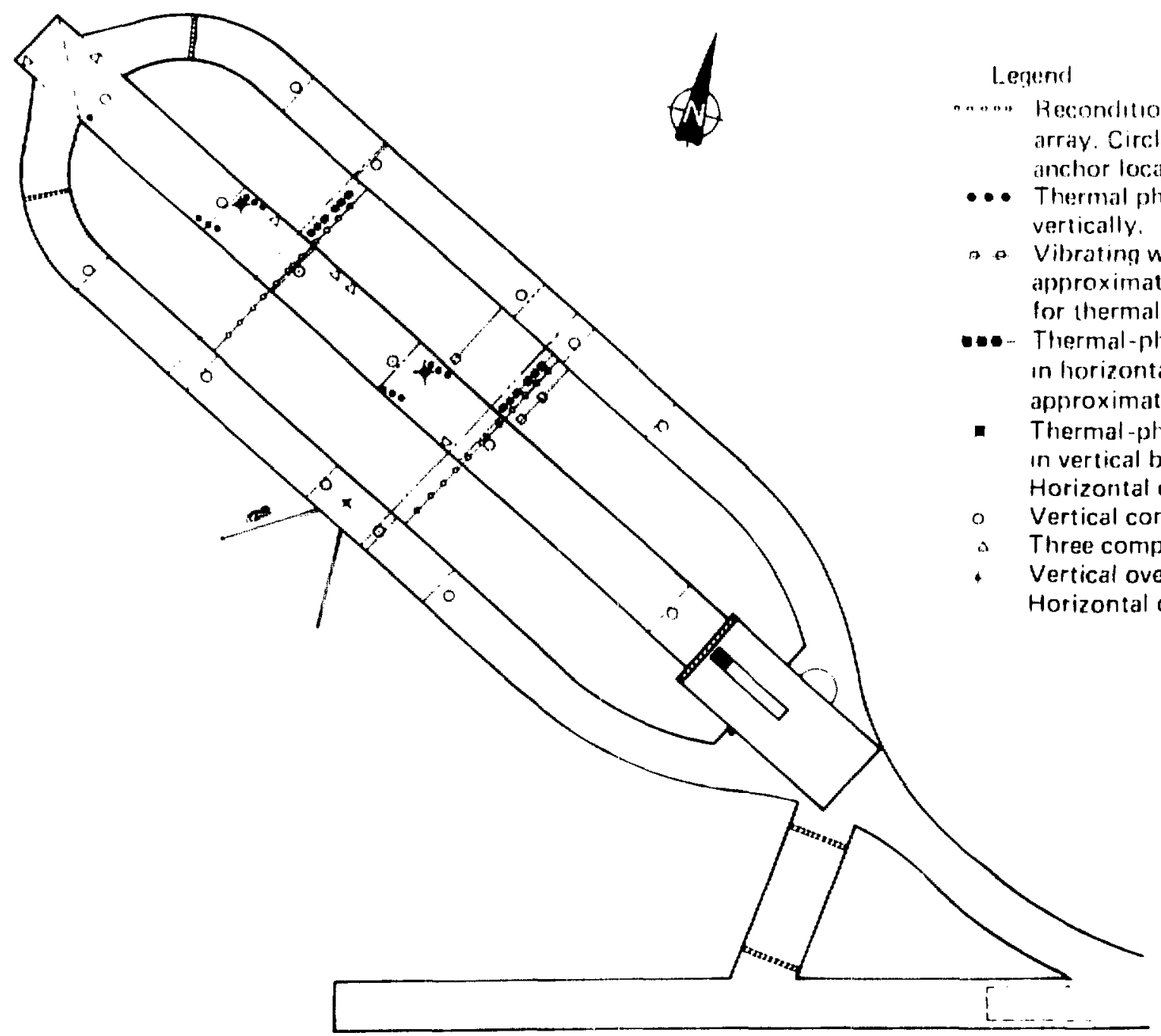

FIG. 15. Plan view of geotechnical instrumentation for heated phase of SFT-C. 


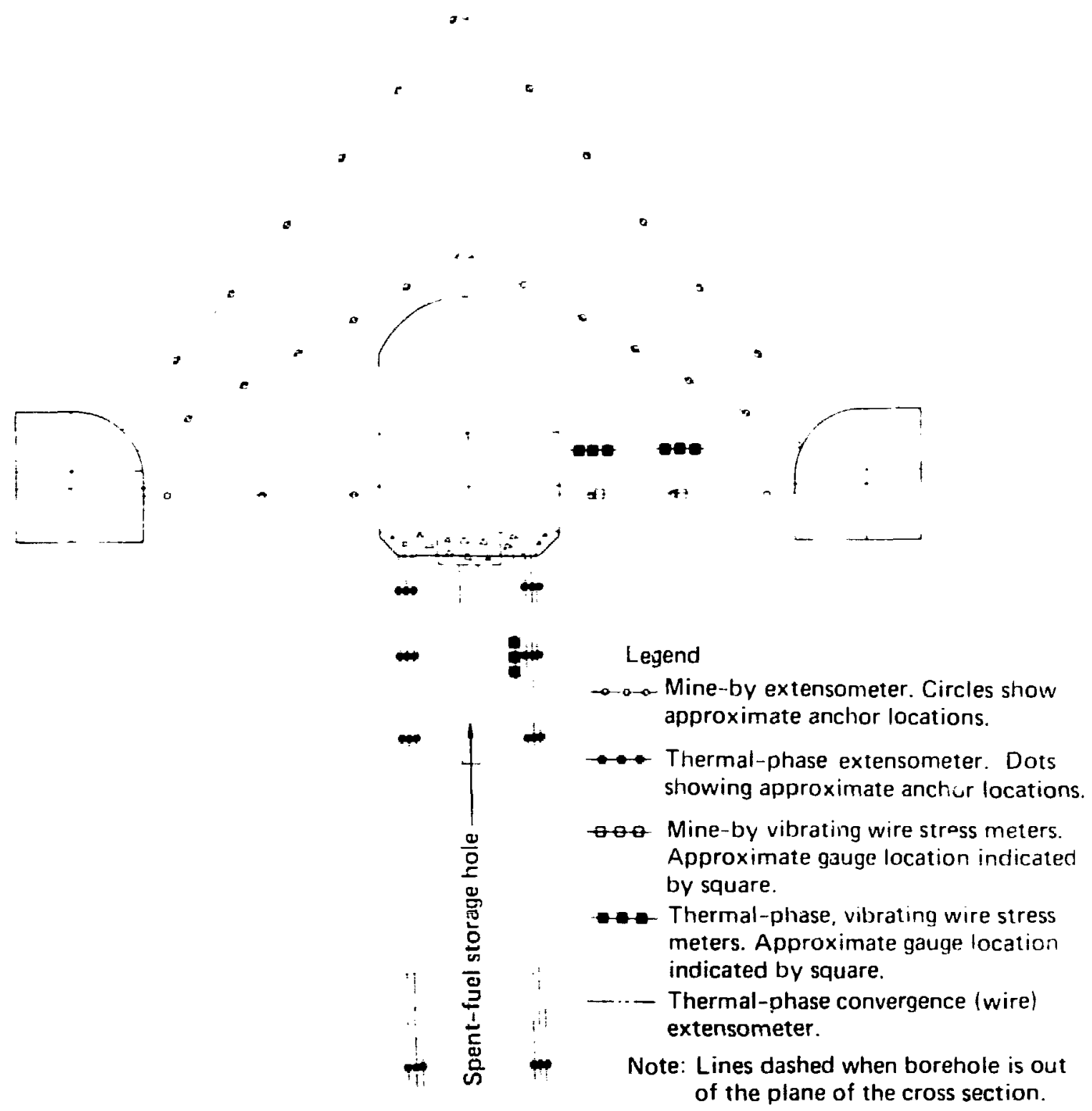

FIG. 16. Schematic cross section of geotechnical instrumentation for heated phase of SFT-C.

DATA ACQUISITION SYSTEM

Two separate stations house the Spent-Fuel Test data acquisition system (DAS). The underground electronics alcove is an area $4.6 \times 9.1 \times 3.0-m-h i g h$, enclosed by gypsum board, located in a cross drift between the tail drift and the railcar room (Fig. 6). This alcove contains the Hewlett-Packard (H-P) 
equipment, which digitizes information from the 900 instrumentation channels for transmission up to the surface via cables in the elevator shaft (Fig. 17). The alcove itself is air-conditioned, monitored for the presence of smoke and flame, and protected by a Halon fire-suppression system. A backup ventilation fan will operate in the event of $\mathrm{A} / \mathrm{C}$ system failure to prevent the $\mathrm{H}-\mathrm{P}$ modules from reaching a damaging temperature. A battery-operated, uninterruptable power system (UPS) is located at the alcove to assure continuous monitoring of critical instrumentation.

At the surface, a $6.1 \times 15.2-\mathrm{m}$ double-wide trailer houses a pair of H-P 21 MXE computers, supporting equipment, offices, and an electronics repair shop (Fig. 18). The trailer was manufactured to strict DOE standards of construction, using only noncombustible materials. This facility is also protected by redundant $A / C$ units, smoke alarms, and a Halon fire suppression system.

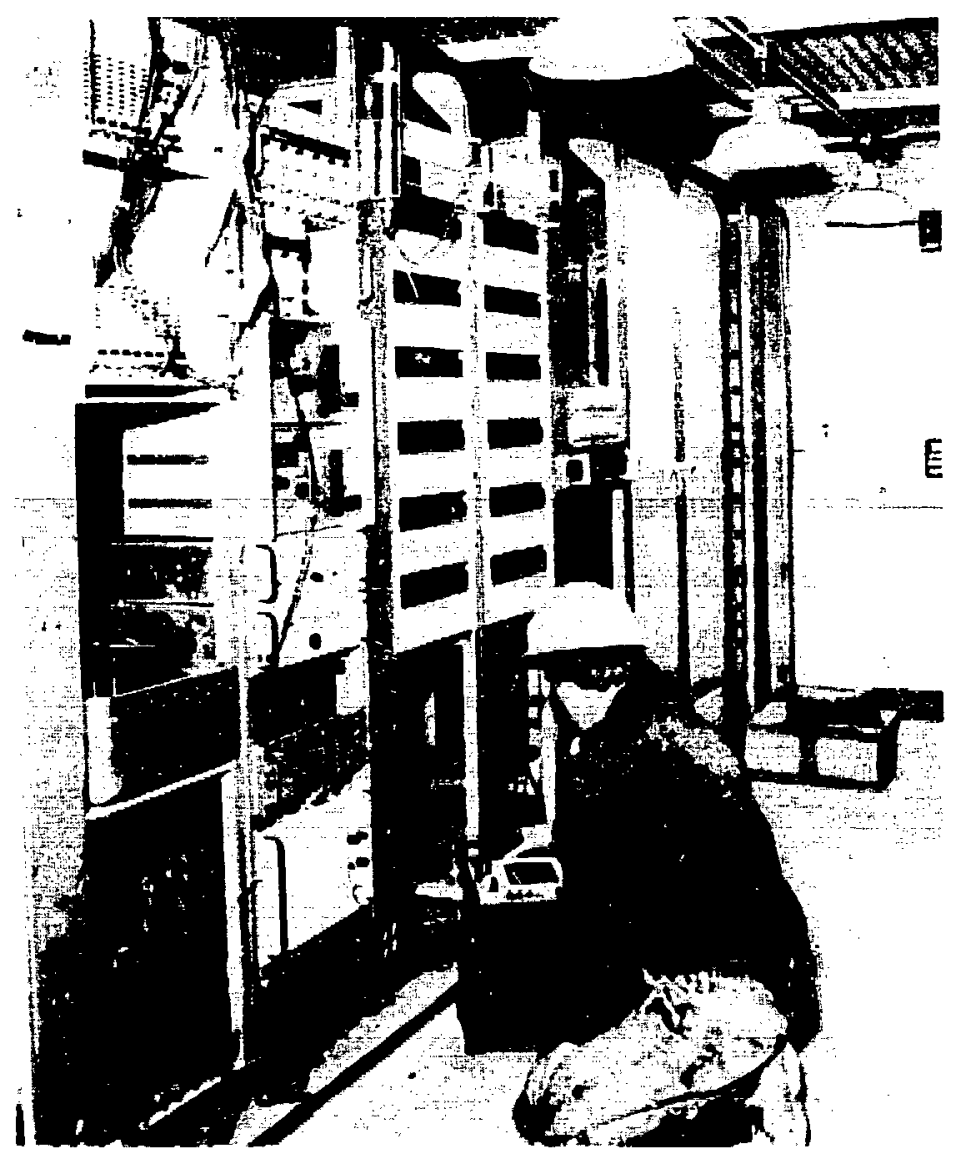

FIG. 17. Instrumentation alcove showing underground portion of data acquisition system. 


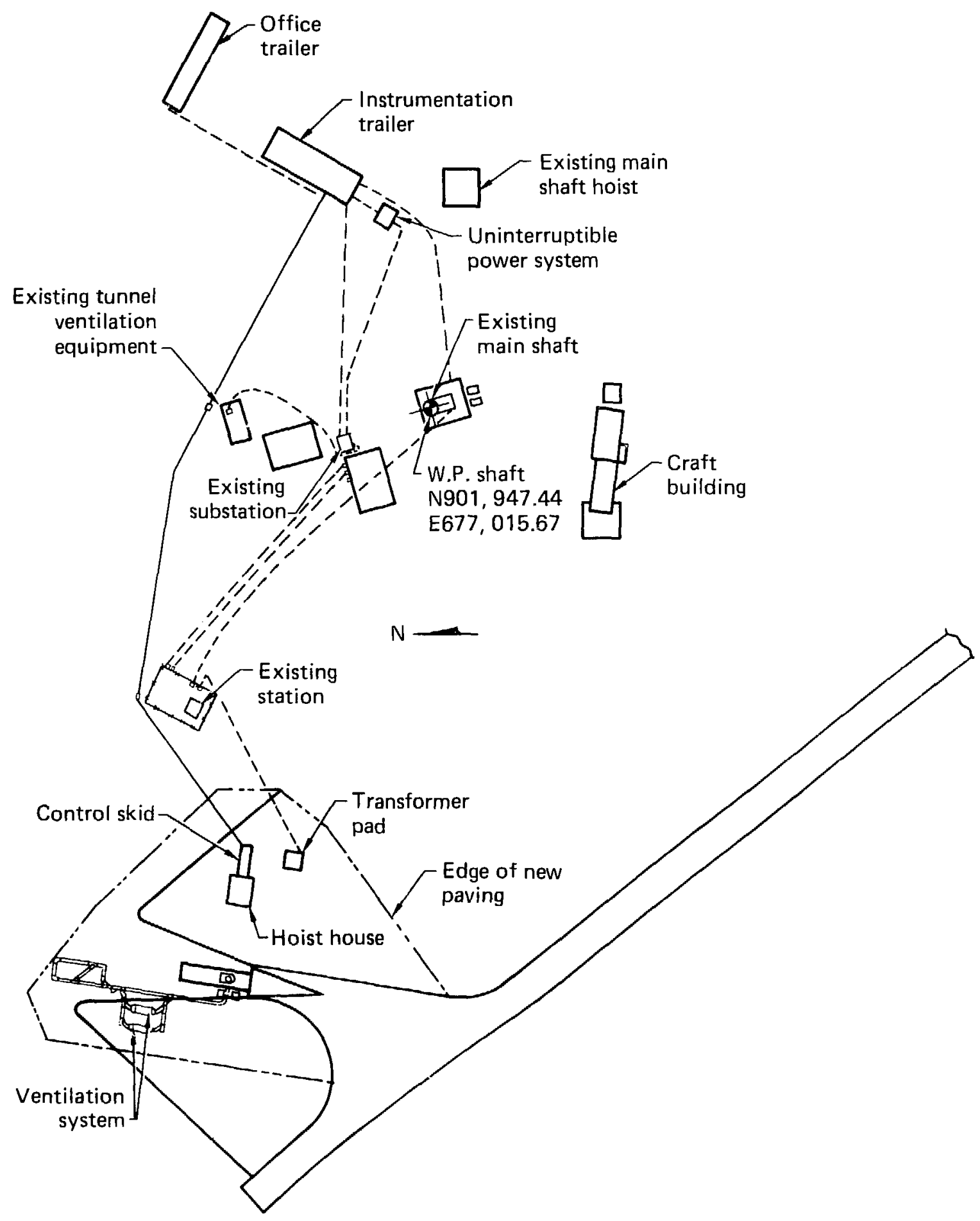

FIG. 18. Layout of SFT-C surface facilities. 
Both the underground alcove and surface trailer fire safety system conditions are remotely monitored by the NTS area fire station.

\section{ELECTRICITY}

Electrical power for the Spent-Fuel Test utilizes the existing main surface substation placed $100 \mathrm{~m}$ northwest of the elevator shaft for the Hard Hat and Pile Driver nuclear weapons effects tests. The substation is fed from the NTS power grid by a 34.5-kV highline with a capacity of $1500 \mathrm{kVA}$. Substation stepdown transformers convert this voltage to $480 \mathrm{~V}$ for distribution to the canister access-hole pad, headframe, ventilation blowers, elevator hoist house, and data acquisition trailers (Fig. 18).

All underground power is taken from an existing 150-kVA, 2400/480-V underground substation. The total connected load for the underground portion of the SFT-C is limited by this transfurmer, which in turn feeds 30 - and 112.5-kVA substations. The principal SFT-C power requirements during the storage phase are shown in Table 7 .

TABLE 7. SFT-C power requirements.

A. Underground

Heater drift heaters $20-2 \mathrm{~kW}$

Canister drift heaters 6-2 kW

Instrumentation alcove racks

Lighting and $a$ ir conditioning

Underground subtotal $87 \mathrm{~kW}$

B. Surface

Data acquisition trailer 5

$\begin{array}{ll}\text { Canister access-hole vent system } & 10\end{array}$

Lighting and air conditioning 25

Surface subtotal $40 \mathrm{~kW}$

Total: $127 \mathrm{~kW}$ 


\section{VENTILATION}

Underground ventilation during construction was provided for by a single 400-hp Buffalo "squirrel-cage" blower tied to the mine workings with two 406-mm-diam ducts in the elevator shaft. This system provided sufficient air Flow in the drifts to rapidly clear diesel equipment exhaust and blasting contaminants from the area. Air was exhausted from the far ends of the drifts through a distribution system of ducts $660 \mathrm{~mm}$ in diameter, through the two 406-mm-diam shaft ducts, to the blower. Fresh air flow came down the $2.4 \times$ 3.7-m elevator shaft, and through the various drifts to the fan lines at the headings. This system continued in operation until the beginning of canister handling exercises just prior to spent-fuel loading.

A completely separate ventilation system was designed for the test operation phase (Figs. 19 and 20). The main criteria for this system are as follows. The ability to:

1. Use the canister access hole as an exhaust line.

2. Discharge at the surface through a high-efficiency particulate air (HEPA) filter system during spent-fuel handling operations.

3. Provide $340 \mathrm{~m}^{3} / \mathrm{h}$ for each person underground during test operations, assuming about $6800 \mathrm{~m}^{3} / \mathrm{h}$ are required at a maximum work force of 20 .

4. Keep drift temperatures below $32^{\circ} \mathrm{C}$ during the initial heating period. Calculations indicate $8500 \mathrm{~m}^{3} / \mathrm{h}$ are required.

5. Maintain positive ventilation away from manned areas outside the canister storage drift.

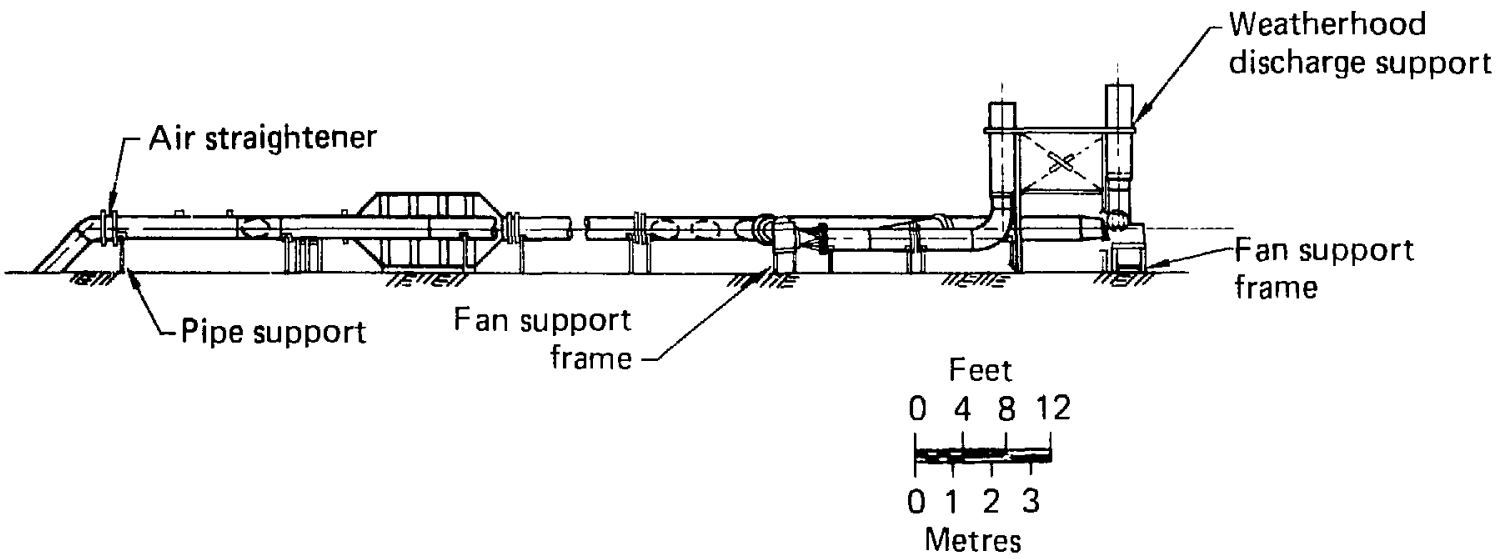

FIG. 19. SFT-C storage phase ventilation system. 


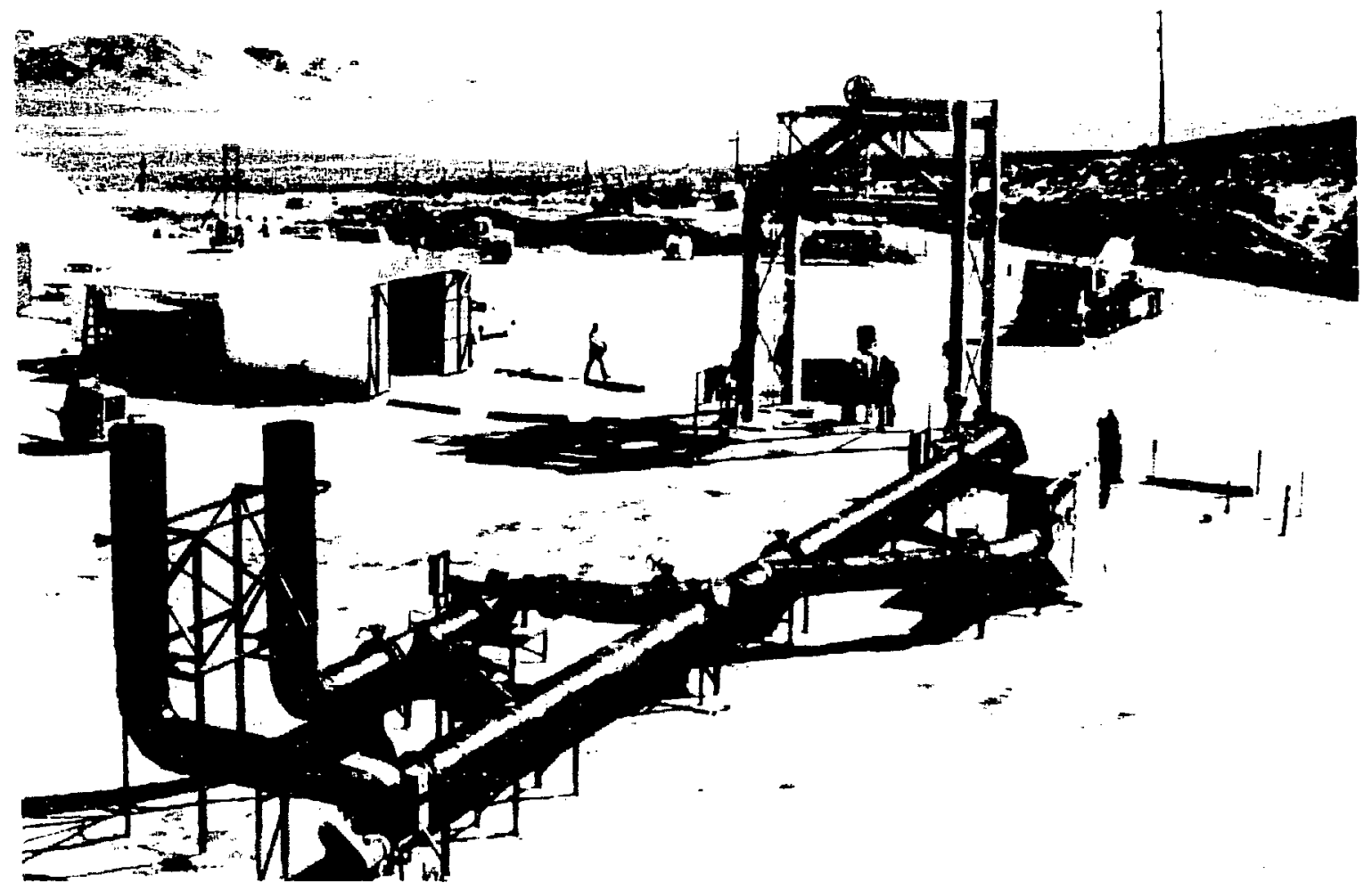

FIG. 20. Surface plant in the vicinity of the canister access hole showing ventilation system, hoist house, head frame, and surface transport vehicle (STV).

6. Continuously monitor radioactive gases and particles, flow, temperature, and humidity.

7. Provide two identical fans capable of use in parallel or series for maximum flexibility in use and duplication in event of fan outage.

During spent-fuel handling in the access hole and canister drift, the dampers regulating flow through the side heater drifts are closed so that all air passes through the damper at the beginning of the canister storage drift opposite the access hole (Fig. 21). This condition sets up a relatively high pressure drop across the loose-fitting accordian bulkhead doors adjacent to the damper. At the surface, the flow is valved to pass through the HEPA filters (Figs. 19 and 20).

In this configuration, any radioactive particulate matter released by an accidental breaching of the canister would be drawn up the access hole and filtered out before exhausting to the atmosphere. 
(B)
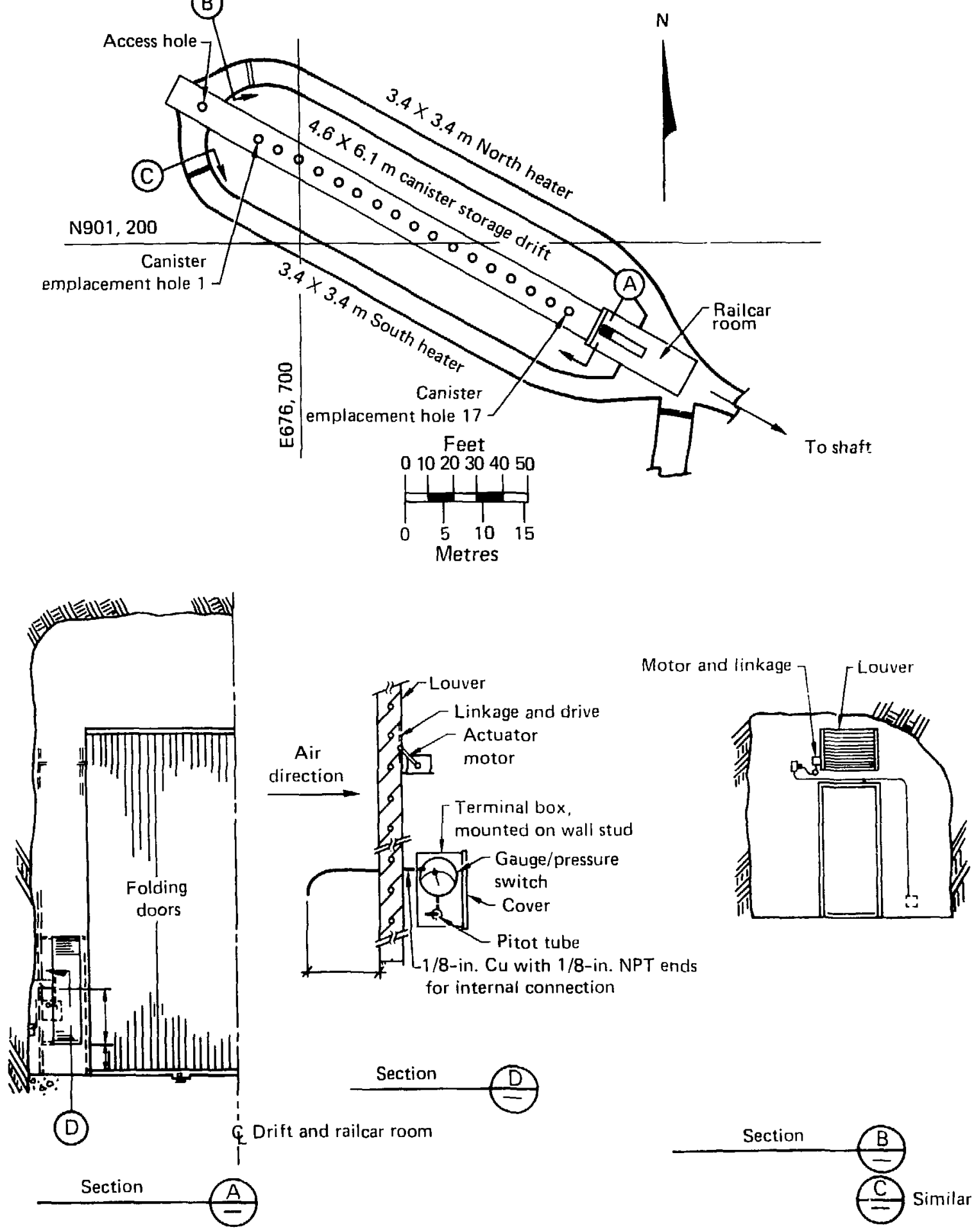

FIG. 21. Flow regulator system for SFT-C subsurface facilities. 
During fuel storage, the dampers at the three drift bulkheads are set to pass $2125 \mathrm{~m}^{3} / \mathrm{h}$ in each heater drift and $4250 \mathrm{~m}^{3} / \mathrm{h}$ in the main drift. This will maintain a safe and reasonably comfortable air flow through all drifts. During this period when particulate release is extremely improbable, the HEPA filters are bypassed. Remote alarms in the drifts and at the surface continuously monitor for radioactive krypton and tritium to warn of a leaking canister.

Air flow, temperature, and humidity meters are periodically read by the data acquisition system to monitor heat transfer and loss from the spent-fuel and electrical heater drifts.

SPENT-FUEL HANDLING SYSTEM

The spent-fuel handling system has three main components. The details of system design and construction are discussed elsewhere. ${ }^{10}$

1. The surface transport vehicle (STV) is a special trailer-mounted self-erecting, steel-walled, shielding cask (Fig. 20). This vehicle is loaded with spent fuel at the EMAD facility $80 \mathrm{~km}$ southwest of the site. It is drawn by a standard highway tractor at speeds up to $55 \mathrm{kmph}$ depending on road surface conditions. The trip is under convoy with continuous radio surveillance and NTS duty officer control. The convoy is made up of a leader car in front, the STV, and a following van equipped and operated by radiological safety personnel. Upon arrival at the access hole, the STV is positioned over the opening and the cask is partially lowered into a pit for shielding purposes. The top gate is opened allowing the canister hoist to raise the canister off the bottom gate. After the bottom gate is opened, the hoist is able to lower the canister down the hole.

2. The canister hoist is a variable-speed, dc-motor-driven machine that has built-in redundancy in each load path to assure utmost safety during the most critical phase of the handling operation. The hoist cable is similar in design to downhole logging cable with 18 pairs of electrical conductors for operation and monitoring of the canister grapple and brake system. This system assures positive fail-safe attachment of the canister to the hoist. A braking system, integral to the grapple, will stop the descent of the canister in the event of a cable or hoist failure.

3. The UTV (Fig. 22) is a rail-mounted, steel-walled shielding cask similar to the STV. It is parked beneath the access hole during lowering to 


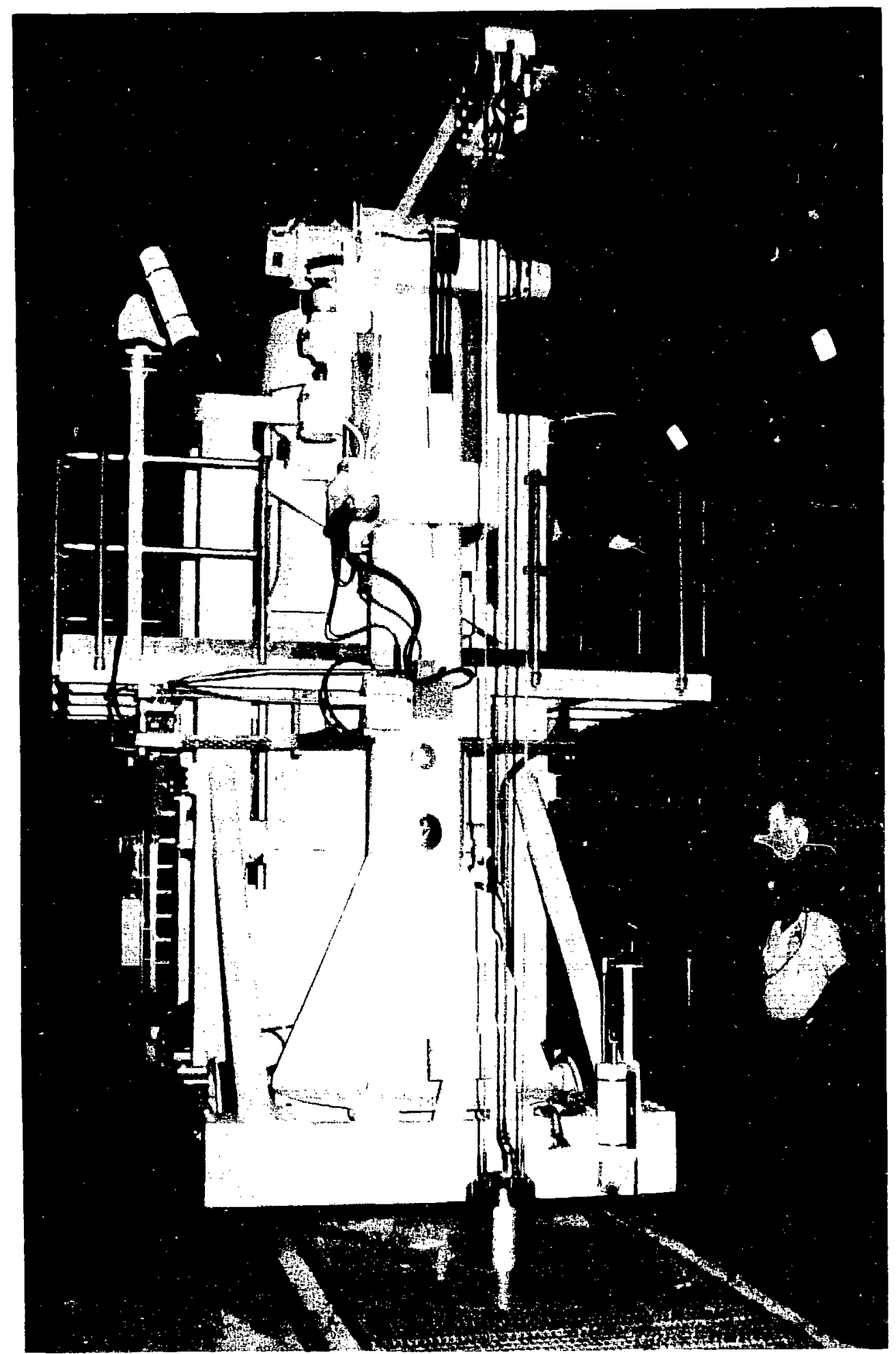

FIG. 22. Underground transport vehicle (UTV) performing trial removal of canister emplacement hole pit plug. 
receive the canister. When loaded, the UTV is remotely shuttled down the storage drift to the appropriate hole for canister emplacement by an onboard hoist.

\section{COST SUMMARY}

The total project cost through completion of emplacement of 11 spent-fuel assemblies was $\$ 18.4$ million. This figure includes all construction, as well as related scientific and technical activities.

Drilling the 762-mm-diam canister-access hole cost about $\$ 1.43$ million or about $\$ 3360 / \mathrm{m}$. Preparation of the site, mobilization, and demobilization are included in this cost.

Construction of the three-drift SFT-C complex, the tail drift, and the alcove cost about $\$ 2.51$ million. About $6700 \mathrm{~m}^{3}$ of granite were excavated at an average cost of $\$ 375 / \mathrm{m}^{3}$. This cost includes all mobilization and demobilization of equipment and personnel, rehabilitation of mucking facilities, and support of some geologic investigations.

The exploratory drilling program produced $480 \mathrm{~m}$ of core from holes $76 \mathrm{~mm}$ in diameter, at a cost of about $\$ 0.25$ million. This indicates an average cost of about $\$ 520 / \mathrm{m}$ drilled. Mobilizason, demobilization, downtime, and "standby" costs are included.

Drilling the 18 610-mm-diam $\times 5.2-m$-deep canister emplacement holes cost $\$ 0.35$ million. This cost, again, includes all activities related to the drilling of these holes included on the work order. The work order included drilling 18 76-mm-diam $\times$ 5.2-m-deep record cores, whict. cost about \$0.05 million according to the data in the previous paragraph. Canister emplacement hole cost is thus $\$ 0.30$ million or about $\$ 3200 / \mathrm{m}$.

Numerous other holes were drilled for instrumentation emplacement. This work order included all holes indicated in Table 8 . The total cost of $\$ 0.31$ million reflects an average cost of about $\$ 290 / \mathrm{m}$.

\section{PROJECT MANAGEMENT}

The initial DOE/NV-LLNL concept for the SFT-C was submitted to DOE/HQ in January 1978. This concept envisioned a considerably less complex test than that finally constructed, and proposed a 20-month schedule for completion. 
TABLE 8. Summary of instrumentation drill holes.

\begin{tabular}{clcc}
$\begin{array}{c}\text { Hole size } \\
(\mathrm{mm})\end{array}$ & \multicolumn{1}{c}{ Drill type } & No. holes & $\begin{array}{c}\text { Total drilled } \\
(\mathrm{m})\end{array}$ \\
\hline 152 & Diamond overcored & 4 & 24.5 \\
124 & Diamond reamed & 26 & 33.5 \\
76 & Diamond cored & 65 & 486.5 \\
64 & Rotary percussion & 6 & 45.7 \\
51 & Diamond cored & 20 & 98.1 \\
38 & Diamond cored & 57 & 388.2 \\
Total: & & & 1076.5 \\
Various & Various & 178 & \\
\hline
\end{tabular}

The fact that a 24-month schedule was achieved in spite of a significantly increased project scope indicates the dedication of all participants to close coordination and management.

In the fall of 1978 , a master critical path schedule (CPS) was developed by LLNL with input from Westinghouse (the supplier of spent-fuel canisters and related haröware), Reynolds Electrical \& Engineering Co. (the NTS construction and support contractor), Holmes \& Narver (A-E for facility design), and Fenix \& Scisson (A-F for drilling and mining). This schedule was revised several times during the project.

The final master CPS contained over 200 nodes describing activities in four major subdivisions: field construction, fuel canister acquisition and encapsulation, data acquisition and instrumentation, and canister handling system. Parallel critical paths occurred in all subdivisions.

In addition to the critical path method (CPM) used for project scheduling, a master completion schedule (MCS) was employed. The MCs listed all activities by work place, optimizing utilization of space and time for all contractors. Weekly updates of the MCS were provided to supervisors and other key project personnel. This management tool provided for a level of detail, based on specific work places, not practical with the CPM.

In order to meet the aggressive schedule of spent-fuel emplacement in early 1980, the CPM indicated that design and construction activities be "fast-tracked" (run in parallel). As soon as sufficient criteria were developed by the LLNL staff for a particular feature of the project, design 
would be initiated (frequently before detailed information had been formally transmitted). Procurement of materials was started as soon as designs were firm so construction delays would not occur. The contractor supervisors were kept abreast of concept development to be able to anticipate construction requirements before they were formalized.

This integrated method of working with DOE management, A-Es, and contractors at all levels of work facilitated project completion by the scheduled date.

While field construction was the exclusive responsibility of REECo, inadequate progress in mining and early indications of cost overruns precipitated a task-force approach to problem solving. The DOE convened the first task force meeting, with LLNL providing expertise in mining from a consultant having international stature in this field. Some improvement in progress was realized through this exercise. Mining efficiency was further improved by close interaction of LLNL geologists and mining engineers with contractor personnel. The most significant contributions of the task force were in bringing actual costs into better conformance with estimated costs and in identifying causes of cost overruns. The major differences between A-E estimates and actual costs occurred because of lower actual production rates with associated higher labor costs and higher actual material costs. Average production cost was reduced $39 \%$ during the first month and a half of 1979. A principal cause of this reduction was the commencement of two-face production in the heater drifts. Increasing the total work force from 50 to 74 men per day (three-shift operation) doubled the total production. This represented an increase in effective production rate of $35 \%$. Other cost increases were a result of changes in scope of work.

\section{OBSERVATIONS AND RECOMMENDATIONS}

Several important lessons were learned in the course of constructing the SFT-C facility. These are expressed here as observations and recommendations, which should be considered when undertaking design, construction, and project management of hard rock waste repositories.

1. The critical path method (CPM) is a valuable tool in project scheduling. Several factors must be kept in mind when developing and applying such a schedule. First, input must be realistic. As noted in this report, 
the desire to complete a project early must be tempered with the realities of delivery times and production rates. The schedule requires input and review from all contractors to ensure realistic scheduling. Second, recognition of critical paths and nearly-critical paths must be obtained by all contractor personnel. This instills the required sense of urgency, which leads to timely project completion. Third, frequent schedule updating is required as new information is obtained. Fourth, it should be noted that CPM is only one of several project management tools. Individual projects may require additional scheduling tools such as the Master Completion Schedule employed at the SFT-C.

2. The use of integrated contractors provides a highly responsive pool of engineering and construction expertise. The team used on this project included Reynolds Electrical Engineering Company, the N'S construction and support contractor; Holmes \& Narver, the A-E for facility design and survey support; Fenix \& Scisson, the A-E for drilling and mining; and Westinghouse Electric Corporation, the supplier of spent-fuel canisters and relatel hardware. The engineering and scientific staff at LLNL and numerous other subcontractors provided the technical skills necessary for the design, fabrication, construction, and operation of the SFT-C and its associated equipment.

There are two principal advantages to the use of integrated contractors. First, required skills are available on short notice. The use of integrated contractors was critical in meeting project time constraints. The continuing development of project scope and criteria during design and construction would have created insurmountable delays and administrative problems in control and cost of changes if field construction was on a bid basis. Second, long-term commitments to personnel are not made by the project. These two advantages minimize cost while maximizing responsiveness.

3. Close coordination with the construction contractor by the lead project agency (LLNL, in this case) and the appropriate A-E groups is required. Accepting contracted work on a bid basis can cause problems in control. This problem also exists when integrated, captive contractors are used. An example is the failure to meet the smooth-wall blasting criteria at the SFT-C. Since REECo had responsibility for mining, blast round development and required training cotld be suggested, but not imposed, by the $A-E$ and LLNL. Of the two consirierations, high production and a stringent criterion of less than 76-mm overbieak, the contractor emphasized high production. 
4. Equipment selection can control production rates and excavation quality. Both captive and noncaptive contractors select equipment based on what they have available, unless the project is large enough to absorb the capital cost of additional equipment. The use of rotary tricone drilling for the canister access shaft and the use of suboptimum drilling equipment for underground excavation are examples of equipment selection based on availability. In the former example, we learned that proper equipment increased esfective drilling rates by more than a factor of 3 . In the latter example, we anticipate that the use of modern hydraulic drills and full-face tunneling technique could increase both prcduction and quality of excavation.

5. Personnel training is essential, even with experienced personnel. Experience is never complete, so personnel must become familiar with new project requirements anü criteria, such as different equipment and geology, and new team member responsibilities and capabilities. Observations at the SFT-C indicate that changing rock type from tuff to granite had a profound effect on how personnel operated their equipment (often applying ton much thrust on the drill steel) and on the design of blast rounds (the familiar tuff rounds produced bootlegs, oversize material, and poor advance rates). We feel that a short training period could have eliminated these and other problems. It would also have reduced the frustration of both miners and supervisors over the results they were obtaining. Improvements in smooth-wall blasting would also have resulted from training.

6. Changes in scope of many tasks occurred as a result of concurrent design and construction activities, although the overall project goals remained the same. Such changes, including changes in drift layout, increased numbers of instruments with associated boreholes, and additional access to the facility, were always accomplished by the team of integrated contractors. As could be expected, additional costs were incurred as a result of such changes. Project funding should be established at a level capable of supporting these changes in scope. We suggest contingency funds at the project level and at NV level. Response to major redirection of the NWTS program cannot be covered by a contingency at these levels, nor should it be.

7. Techniques for estimating project ccst produced markedly different estimates from REECo (the construction and support contractor) and $F$ \& $S$ (the A-E for drilling and mining). REECo estimates of various cost categories ranged from 110 to 3008 of the $F$ \& s estimates. The REECo mining cost 
estimate was 1578 of the $F \& S$ estimate. Most of these differences are due to F S S's use of a production rate 438 higher than that of REECo. A change in drift layout that occurred between the time that estimates were made and funding was secured, and between funding and the onset of construction, contributed to an increase in actual costs of about 298 over REECo estimates, or about 1038 higher than $F \& S$ estimates. Although it is unclear what portion of the cost inc:aase was due to change in scope, most of the 298 is probably related to operation of two faces rather than one (based on task force findings). We, thus, conclude that the construction contractor can provide better estimates than the A-E when contractor-specific historical data is availabie. Although such data is often held "company confidential", this should not be true within the team of integrated contractors. Construction and A-E contractors should share the available data to support accurate, timely cost estimacing.

8. Anticipated economy of scale should be a concern of agencies interested in developing the proposed DOE Test and Evaluation Facility (TEF) and full-scale hard rock repositories. Since total cost for spent-fuel emplacement was $\$ 18.4$ million, and 18 emplacement holes were drilled (ll spent fuel, 6 electrical simulators, and 1 practice hole), cost of emplacement was about $\$ 1$ million/canister.

Several factors were present in the SFT-C that make the $\$ 1$ million/canister cost estimate inaccurate for a 1-rge-scale repository or, possibly, for a TEF. The intent of this discussion is not to make an accurate estimate, but to bring to light areas that could significantly affect the estimate. First, only an emplacement shaft was sunk, since a man-and-materials shaft was in existence. Sinking a $25-\mathrm{m}^{2}$ cross-section shaft may cost about $\$ 10,000 / \mathrm{m}$ or $\$ 10$ million for a $1-k m-d e e p$ shaft in granite. This cost would be spread over the number of canisters emplaced in the facility. For a 250-canister TEF, the cost would be $\$ 40 \mathrm{~K}$ per canister. Second, although only 18 emplacement holes were drilled at the SFT-C, sufficient excavation and drilling were performed for about twice as many canisters. This factor alone would cut the apparent cost in half. Third, the waste package cost was small compared to that of an actual repository, due to the simple canister and liner zonfiguration. Some estimates place waste package cost at about $\$ 100 \mathrm{~K} / \mathrm{canizter}$. Packaging facility costs are included in this estimate. Fourth, construction and A-E staffs would scale with repository size, but engineering and scientific staff should not contribute as large a percentage as this to the cost of a 
large repository. Costs of engineering and scientific staffs could constitute

- an equal or larger percentage of total cost at a TEF due to the evaluative nature of such a facility. Fifth, optimization of mining and drilling technique could produce substantial decreases in unit costs. Mining and drilling in welded tuffs, for example, are not expected to be significantly less costly than in granite, assuming similar equipment is employed. Sixth, numerous mine plant costs such as ventilation and air conditioning, water pumping, and hoisting can be expected to increase with depth and size of the facility. Seventh, handling system costs will be spread over a larger number of canisters, decreasing the cost per canister substantially.

We believe that a detailed cost assessment of design, construction, operation, and decommissioning of a TEF or a full-scale repository is appropriate at this time, based on current data.

\section{SUMMARY}

Spent fuel from a commercial nuclear reactor is currently in test storage $420 \mathrm{~m}$ below surface in a granitic medium at the Department of Energy's Nevada Test Site. Design and construction of the SFT-C began june 2, 1978, and emplacement of 11 canisters of spent fuel was completer May 28, 1980. Total project cost through spent-fuel emplacement was $\$ 18.4$ million. Spent-fuel retrieval is planned for 1985 .

In addition to a rigid schedule, several major design constraints were incorporated in the project. These included site geology, surface topography, existing facilities, equipment size and geometry, and the technical objectives of the test. Close coordination and vigorous execution of the project plan by all agencies involved resulted in timely completion of the SFT-C construction. 
F. D. Waltman (F\& S) provided a history of mining at the Spent-Fuel Test-Climax that contained much of the data used in developing this report. G. W. Adair (REECO) provided information on mining and drilling equipment used in the development of the SFT-C.

The authors acknowledge the careful reviews and helpful comments of L. D. Ramspott, L. B. Ballou, D. G. Wilder, and J. L. Yow, Jr. We also express our appreciation to J. F. Clark and D. M. Verrett, who typed this manuscript.

\section{REFERENCES}

1. L. D. Ramspott, L. B. Ballou, R. C. Carlson, D. N. Montan,

T. R. Butkovich, J. E. Duncan, W. C. Patrick, D. G. Wilder, W. G. Brough, M. C. Mayr, Technical Concept for a Test of Geologic Storage of Spent Reactor Fuel in the Climax Granite, Nevada Test Site, Lawrence Livermore National Laboratory, Livermore, Calif., UCRL-52796 (1979).

2. D. G. Wilder and W. C. Patrick, Geotechnical Status Report for Test Storage of Spent Reactor Fuel in Climax Granite, NTS, presented at the AEG Symposium on Geological Disposal of High-Level Radioactive Waste, October 1980. Lawrence Livermore National Laboratory, Livermore, Calif., preprint UCRL-85096 (1980).

3. F. E. Heuze, W. C. Patrick, R. V. De la Cruz, C. F. Voss, In Situ Deformability, In Situ Stresses, and Poisson's Ratio, Climax Granite, NTS, Lawrence Livermore National Laboratory, Livermore, Calif., UCRL-53076 (1981).

4. F. Maldonado, Summary of the Geology and Physical Properties of the Climax Stock, Nevada Test Site, usGs, Denver, Colo., Open-File Report 77-356 (1977).

5. L. Obert, Shot Hard Hat, Static Stress Determinations, Department of Defense, POR-1804 (WT-1804), Washington, D.C. (1963).

6. F. H. Wright, Shot Pile Driver, In Situ Rock Stress (U), Defense Atomic Support Agency, Washington, D.C. (1967).

7. D. P. Krynine and W. R. Judd, Principles of Engineering Geology and Geotechnics, (McGraw-Hill Book Co., New York, 1957). 
8. K. Szechy, The Art of Tunnelling, (Akademiai Kiado, Budapest, 1966).

9. W. L. Ellis, In Situ Stress Determinations at the Spent Fuel Test-Climax, USGS (in preparation).

10. J. D. Duncan, P. A. House, and G. W. Wright, Spent Fuel Handling System for a Geologic Storage Test at the Nevada Test Site, presented at the ANS Summer Meeting, June 1980. Lawrence Livermore National Laboratory, Livermore, Calif., preprint UCRL-83728 (1980).

11. D. N. Montan, Thermai Analysis for a Spent Reactor Fuel Storage Test in Granite, presented at the International Symposium on the Scientific Basis for Nuclear Waste Management, November 1980. Lawrence Livermore National Laboratory, Livermore, Calif., preprint UCRL-83995 (1980).

12. W. Bradkin and D. N. Montan, Final Report on Heater Test \#I in Climax Granite, Lawrence Livermore National Laboratory, Livermore, Calif. (in preparation).

13. W. C. Patrick and W. G. Brough, Response of Borehole Extensometers to Explosively Generated Dynamic Loads, Lawrence Livermore National Laboratory, Livermore, Calif, UCRL-53087 (1980).

14. A. B. Cummins and I. A. Given, eds., Mining Engineering Handbook (Society of Mining Engineers of AIME, New York, 1973).

15. G. Nord, P. Persson, and D. Prader, "European Views on Mechanical Boring versus Drill and Blast Tunnelling," in Proceedings of the 1979 Rapid Excavation and Tunnelling Conferences (Society of Mining Engineers of AIME, New York, 1979).

16. R. C. Carlson, W. C. Patrick, D. G. Wilder, W. G. Brough, D. N. Montan, P. E. Harben, L. B. Ballou, and H. C. Heard, Interim Report on the SFT-C Technical Measurements Program, Lawrence Livermore National Laboratory, Livermore, Calif., UCRL-53064 (1980). 